Article

\title{
Impact of the COVID-19 Pandemic on the Tourism Industry: Applying TRIZ and DEMATEL to Construct a Decision-Making Model
}

\author{
Dong-Shang Chang and Wei-De Wu *
}

check for updates

Citation: Chang, D.-S.; Wu, W.-D. Impact of the COVID-19 Pandemic on the Tourism Industry: Applying TRIZ and DEMATEL to Construct a Decision-Making Model. Sustainability 2021, 13, 7610. https://doi.org/10.3390/su13147610

Academic Editor: Kisang Ryu

Received: 20 May 2021

Accepted: 5 July 2021

Published: 7 July 2021

Publisher's Note: MDPI stays neutral with regard to jurisdictional claims in published maps and institutional affiliations.

Copyright: (c) 2021 by the authors. Licensee MDPI, Basel, Switzerland. This article is an open access article distributed under the terms and conditions of the Creative Commons Attribution (CC BY) license (https:// creativecommons.org/licenses/by/ $4.0 /)$.
Department of Business Administration, National Central University, Taoyuan City 320317, Taiwan; dongshang168@gmail.com

* Correspondence: ddavid1072700@gmail.com
Abstract: The impact of the COVID-19 pandemic on the tourism industry is still being sustained, and the response of the tourism industry is an indispensable element that is increasingly recognized. This response has led to the emergence of literature about the impact of COVID-19 on the stakeholders of the tourism industry, thereby contributing to the industry. Nonetheless, the criteria factors and investigated practices for the implementation of decision-making by stakeholders in the tourism industry have not been fully explored. This study adopts Teorija Rezhenija Izobre-tatelskikh Zadach (TRIZ) principles and Decision-Making Trial and Evaluation Laboratory (DEMATEL) methods to construct a gap model of tourism stakeholders (GMTS) which solves the tourism industry decisionmaking problem under COVID-19. With a research background in Taiwan's tourism industry stakeholders made up of 15 expert participants, GMTS identified 11 criteria factors, of which the three most important criteria factors provide decision-making directions. The causal relationship between these criteria factors was examined, and a causal diagram was drawn to clarify the most important criteria factors. This research examined the criteria factor implementation perspective. Travel "bubble zones" that ensure both "safety and quality" were concluded upon under government policies in the countries and regions of the world. Furthermore, the tourism industry is responsible for the overall "planning and management" of the travel "bubble zones". Therefore, the "quality management" criteria factor provides important key decision-making for tourism stakeholders. The research indicates that it is recommended to attach importance to the "quality management" of the international travel "bubble zone" as the priority decision-making criteria factor under the pandemic. Furthermore, conversion policies and tourism regulations are secondary criteria factors for improvement; when these two criteria factors are immediately improved, other criteria factors will be affected simultaneously and the degree of improvement will be weakened. In addition, GMTS was developed for the tourism industry. The article also provides research literature and practice implications for stakeholders in the tourism industry, thereby providing insight for tourism to obtain a clear understanding of how to prepare for the implementation of sustainable development.

Keywords: COVID-19; tourism stakeholders; TRIZ; DEMATEL; GMTS

\section{Introduction}

Zurab Pololikashvili, secretary-general of the UNWTO, stated that "Growth in international tourist arrivals and receipts continues to outpace the world economy and both emerging and advanced economies are benefiting from rising tourism income [1]". In 2019, the total international tourist arrivals worldwide were 1460 million, with total international tourism receipts of USD 1481 billion; Asia and the Pacific had 362 million tourists, with receipts of USD 443 billion [2]. In 2019, in Taiwan, tourist receipts and expenditure totaled USD 535.44 billion, with a total number of tourists of 28.9 million, including inbound and outbound tourists (international travel); the number of people engaging in Taiwanese domestic travel numbered over 160 million [3]. Taiwan has a population of 23.8 million [4]. 
Tourism is one of the most important industries in Taiwan. On 23 January 2020, Wuhan declared a lockdown. On January 30, the World Health Organization (WHO) declared the outbreak a global health emergency. On 11 March, the WHO declared the outbreak a COVID-19 pandemic; on 20 April, 100\% of worldwide destinations introduced travel restrictions; in 2020, the number of international tourists suffered $70 \%$ to $75 \%$ negative growth; 100-120 million direct tourism jobs at risk, and international tourism could plunge to the levels of 1990 [5]. Tourism mobility led to COVID-19 becoming a global pandemic [6]. The irresistible risk industry is already synonymous with tourism. It is an unstable industry. In 2003, 2 million tourists were lost due to SARS. In 2009, the Global Economic Crisis reduced the number of tourists by 37 million. In 2020, COVID-19 caused a reduction of 1.1 billion tourists, and a loss in international tourism receipts US\$ 1.1 trillion [5]. The tourism industry is the most frequently impacted industry under the crisis $[7,8]$. Several researchers have highlighted that the impact of COVID-19 on the tourism industry is significant [9-13]. However, impactive decision-making is lacking, and few studies have determined the solutions in the tourism industry. How the tourism industry survives under the crisis context is an urgent issue.

The tourism industry must respond to the tourism disaster caused by COVID-19. The world has been in a panic in the past year, and tourism-related industries have suffered unprecedented significant effects. From the disappearance of international tourists to the instantaneous cessation of the tourism market, many related industries ceased operations. [14]. The COVID-19 pandemic has caused a significant crisis to all of the industries in the world [15], and this crisis has a significant impact on the tourism industry [12]. Scholars believe that global tourism and population movements have caused the emergence or re-emergence of infectious diseases as one inevitable result of such movements [16]. The early evidence of the effects of travel, flights, cruise ships and accommodations under the pandemic is devastating [17]. The global pandemic of COVID-19 has severely hit economic industries such as tourism, hospitality and airlines [18]. The government has forcibly closed hotels, restaurants, attractions and tourism-related businesses [19]. Travel and tourism have always been significant factors in globalization, and are the industries most affected by the COVID-19 pandemic [20]. The COVID-19 pandemic has not been controlled, and the situation is unpredictable; therefore, research is essential for the restoration of tourism and the associated industries [21]. In the COVID-19 pandemic, for the tourism industry to form a new normal [11,22], a new approach to the crisis is required. Nevertheless, to the best of our knowledge, the previous literature has not found a crisis solution for tourism industry stakeholders. Most of the early literature may be limited to the exploration of a wide range of issues related to the quantitative or qualitative nature of second-hand data analysis related to tourism issues [23-27], tourism management issues and related strategic issues under the pandemic [28-33], and the satisfaction issues of accommodation and restaurants under the pandemic [34-37]. Some of the researchers study the economic issues that affect the tourism industry in the COVID-19 pandemic [38-44], discuss the psychological issues of travel stakeholders in the pandemic [45-50], or perform research on Tourism and Virtual Reality (VR) [51-53]. Past research has focused on six functions. When tourism resources are invested, they cannot provide tourism stakeholders with the correct decision-making methods efficiently and quickly. In order to overcome this situation, we propose a decision-making method for tourism stakeholders to address these problems.

The past literature shows the significance of the issues of cooperation between the tourism industry and its partners [54,55]. Tourism stakeholders include tourists, travel companies, travel providers, destination organizations, governments, local communities, and practitioners [11]. Many studies discuss the hospitality industry, the transportation industry, travel companies, and government in the tourism industry, but research discussing a gap model of decision-making is lacking. Therefore, this research will adopt innovative methods to construct a GMTS. Kock and Assaf [56] aimed to advocate for the originality of tourism research. They hoped that tourism scholars would propose an innovative and creative transformation process for the tourism industry [57]. Owing to the fragmented nature 
of the tourism industry, any person or organization that can involve disaster management or beneficial participants in the tourism industry is a stakeholder of the industry [58]. Tourism has been widely recognized as a sustainability industry, and stakeholder collaboration for the sustainability of tourism development has been examined [59]. Using Teorija Rezhenija Izobretatelskikh Zadach (TRIZ) principles, the Decision-Making Trial and Evaluation Laboratory (DEMATEL) has been applied to complex and interrelated group problems, solving contradictions in the care cloud system and innovating the principles of the long-term care cloud system [60]. Altuntas and Gok [61] adopted the DEMATEL method to evaluate COVID-19 quarantine decisions based on the number of visitors and the local population, solving complex problems and decision-making criteria factors.

This research uses the TRIZ principle to reason about the issues among relevant stakeholders in the tourism industry, to clarify the complex relationship results produced by contradictory problems across industries, to resolve contradictions and innovate principles, and to determine the extent of influence between innovation principles and which principles have exerted the most critical impact. Experts' questionnaires are used from hospitality, transportation, travel companies, academic universities and the government. Methods such as multi-criteria decision-making (MCDM), explanatory structure modeling and DEMATEL are used to determine the degree of influence between the criteria factors, and to make decisions. First, the information on the issues that led to the contradictory system construction is summarized; second, the innovative principles of the system are derived in order to adopt TRIZ heuristic reasoning; third, these innovative principles are evaluated by adopting the expert questionnaire survey approach, which uses DEMATEL to measure the standard steps and compute the key innovation principles, such as the criteria factors and feasibility. This study aims to provide GMTS in order to address this issue; tourism stakeholders will establish the new GMTS to solve the dilemma under the influence of COVID-19 and provide research literature and practical applications in order to bridge the research gap. This article has three aspects. First, this research provides a new model which integrates the TRIZ and DEMATEL methods to solve the problems of tourism stakeholders. Second, this study identifies the decision-making criteria factors implemented by tourism stakeholders so that decision-makers can evaluate their industry's approach to sustainable development. Finally, this study explores the practice of the identified criteria factors that provide stakeholders with insight into the existing capabilities in the implementation of decision-making under crisis, and this research will drive useful implications for stakeholders in the tourism industry. On the contrary, if the relevant stakeholders in the tourism industry cannot make effective decisions to face the crisis, they will not be able to sustain the sustainable operation of the industry.

\section{Literature Review}

\subsection{The Hospitality Industry and the COVID-19 Pandemic}

The COVID-19 pandemic has restricted interpersonal interaction, and many industries, including hotels and tourism, have been severely affected [62]. The uncertainty of economic recovery and the continuous spread of COVID-19 have caused millions of people to suddenly lose their jobs; the hospitality industry was one of the first industries to do so [63]. Hospitality and tourism, especially in parts of Asia, Europe and North America, have been affected in a manner unseen in half a century [64]. Many hospitality businesses face existing global challenges $[65,66]$. Some of these are significantly detrimental to international hotel industry operations, including the long-term inflict of the COVID-19 pandemic [67]. The COVID-19 pandemic has introduced difficulties to hotels in major cities in the United States as they continue to operate [68]. In Hong Kong, COVID-19 is seriously damaging the operations of the global tourism hotel industry [69]. In Malaysia, COVID-19 has severely affected the occupancy rate of hotels, with Kuala Lumpur having the largest number of cancellations [70]. In China, they are studying the impact of the pandemic on the hospitality industry, and whether it will change the lifestyle choices, travel behavior and preferences of tourists in the short and long term [71]. In the Spanish hospitality industry, economic 
and tourism activities are generating an economic crisis [72]. In Italy, hotels and bed and breakfasts require financial support [73]. In India, the discussion database papers analyzed the hospitality industry during the pandemic; the first three themes were the recovery of the hospitality industry, market demand and the loss of revenue [74]. In the Vietnamese hotel industry research, the relationship among the hotels' responses to COVID-19 and employee satisfaction was examined [75]. In Seoul, South Korea, the hotel industry is highly vulnerable to health, disasters and other risks; therefore, the number of tourists is insufficient, the occupancy rate is insufficient, and the hotel industry has suffered huge economic losses [15].

\subsection{The Transportation Industry and the COVID-19 Pandemic}

Transportation is the vector through which pathogens are distributed on a regional and global scale. Given that tourism has the characteristic of needing to move [76,77], tourism indirectly supports pandemics. Since the outbreak of COVID-19, the scale of the global crisis has been huge due to restrictions on the use of transportation by countries' authorities around the world; global mobility has ceased [78]. Tourists were infected with COVID-19 on cruise ships, which occurred in countries such as France, Japan, the United States and Australia, resulting in many countries banning cruise ships from docking in their ports [79]. A high risk of influenza infection has been found in transportation vehicles, such as cruises, airplanes, or travel groups [80]. "The spread of covid-19 through frequent long-distance travel, massive cruise ships, and short distance flights" [81]. The COVID-19 outbreak has caused border closures, domestic and international travel has been stopped, and 65 international airlines have reduced flights by 95\% [82]. The Allplane website released a piece of news, indicating that the "airline bankruptcy list has been made public"; thirty airlines worldwide declared bankruptcy [83]. "This is an emergency airline around the world is struggling to survive [84]". Approximately 25 million jobs in the tourism industry, the aviation industry, and related value chains are at risk in China during the COVID-19 crisis [84]. In Australia, domestic flights have only reached 10\% of their preCOVID-19 numbers [84]. The demand crisis faced by European airport operations under the COVID-19 pandemic, and the cost to achieve viability [85]. Geneva ATAG indicates that the decline in air transportation this year caused by the COVID-19 pandemic in 2020 will result in the loss of 46 million jobs provided by global aviation [86]. In Malaysia, airlines are facing the risk of bankruptcy, and the airline has asked the Malaysian government to intervene to provide support and assistance to the aviation industry [70]. In Hong Kong, by pre-purchasing 500,000 tickets from Hong Kong-based airlines, the government will provide another USD 260 million in relief to inject liquidity into the airlines [84]. The COVID crisis has led to an unprecedented reduction in the number of tourists, and airport revenues have also dropped significantly [85].

\subsection{COVID-19 Severely Hit the Travel and Tourism Industry}

Due to globalization factors, tourism has been made available to many people, especially the middle class. Therefore, tourism has become one of the largest industrial fields worldwide in the past two decades [87]. The global economic issues caused by the outbreak of the COVID-19 pandemic are unprecedented for the tourism industry, despite it having been previously afflicted by various crises. The tourism industry is the sector most affected by the situation; because the borders are closed, global destinations are inaccessible [88]. The number of international tourists decreased by 1 billion in 2020 [89]. A study in South Korea highlighted that "untact" is a health protection behavior in the tourism industry. The purpose of the research was to explore the impact of COVID-19 risk perception on the behavioral intentions of untact-tourists, based on the framework of the health belief model and extended planning behavior theory; the results provide timely and insightful enlightenment for tourism practitioners [90]. In Vietnam, they studied the impact of COVID-19 on the tourism industry and the government's response, and interviewed 80 tourism practitioners; the results showed that the government's stimulus 
plan helped the tourism industry recover, and various practices and opportunities for travel stakeholders were explored [91]. In the Czech Republic, research has discussed the impact of the COVID-19 pandemic on rural tourism [92]. In Queensland, Australia, the relationship between COVID-19 social distancing measures, travel restrictions and cultural tourism in four regions was investigated [93]. In Africa, the current pandemic highlights the fragility of the tourism industry's globalization, and the continent, which relies on global visits and global capital, has suffered huge losses [94].

\subsection{Government and the COVID-19 Pandemic}

The COVID-19 pandemic, following the Enlightenment and the Industrial Revolution in 1700, is the most recent manifestation of the continuous development and progress of worldwide modernization and globalization [20]. Many exchanges in global economic activity have been reduced, and governments in many countries and regions have imposed unprecedented restrictions on the movement and behavior of their populations [95]. The governments of all regions should face the serious impact of the inbound and outbound tourism travelers on the pandemic, even though the economic contribution of international tourism was previously huge [96]. Therefore, the government's role is critical to the tourism industry's recovery $[97,98]$. Government warnings and travel bans exacerbate the negative results of the tourism industry [99]. Assuming a link between tourism consumption and the risk of health disasters, because travel increases the risk of infection, governments have imposed travel bans [100]. Therefore, travel companies are required to find innovative conditions [101]. The government needs to seek alleviation measures to support the nonimplementation of layoffs, reducing the negative impact of perceptions of job insecurity [15]. In China, research on the social impact of COVID-19 on the tourism and hospitality industry has recommended that government departments and the tourism and hospitality industry tailor travel arrangements according to tourists and apply them to the global tourism market [71]. In Malaysia, the government announced the four phases of the "Movement Control Order," which will involve signing a contract with the tourism industry in Malaysia during the period of the prohibitions and the formulation of effective policies to assist the tourism industry [78]. In Singapore, the research from the SARS experience in 2003 was used for the outbreak of COVID-19 in 2020; the government adopted three measures, including travel, healthcare and community measures, to curb the spread of COVID19 [102]. A study in Kyoto, Japan analyzed the dynamic process of tourism demand recovery and the applicability of effective policies using the contingent behavior method of quantitative research [103]. In Montenegrin, the government, which is focused on tourism, has responded with appropriate macroeconomic policy responses since the outbreak of the COVID-19 [104]. The duration and impact of the crisis on airports will depend on the containment of the virus and the effectiveness of monetary and government fiscal stimulus programs [85].

\subsection{Tourism Stakeholders and the COVID-19 Pandemic}

Stakeholders in the tourism industry, such as hotels, agents and attractions, are mostly small and medium-sized companies or family-run businesses with "independence" characteristics [105]. Stakeholders might choose to compete or collaborate (or compete and collaborate simultaneously) with their counterparts under different circumstances [106,107]. These stakeholders are the key players in strategic planning, tourism management, or operations [108]. Evidence shows that, during the pandemic, the transportation industry, the hospitality industry, and travel companies are reducing labor and increasing layoffs [65]. Stakeholder relationships come from issues that are critical to creating and distributing value [109]. A study in China analyzed the conflicts between road- and roadless-access tourism in China's large new national park, and a differential tourism stakeholder analysis was conducted [110]. A study in Taichung, Taiwan that used social exchange and stakeholder theory investigated the effect of residents' perceived benefits and costs on the subjective well-being and support of megaevents [111]. A study in Samoa, a tourism 
destination in the South Pacific, discussed the COVID-19 pandemic posing a public health threat to Pacific Island countries; the World Health Organization worked with regional stakeholders to respond to Samoa's points on pandemic prevention [112]. In Singapore and Bangkok, a study aimed to curb the on-site vandalism of tourist attractions and participate in tourist attraction management surveys with multiple stakeholders [108]. Collaboration between stakeholders is a criteria factor of disaster management [58]. For the recreation of tourism, stakeholder theory has been adopted to determine the effects of tourism and other events $[113,114]$. In Canada, a study examined the concept of destination and DMO-related tourism success, and determined whether a relationship existed between the two using research methods such as qualitative research on interview methods and interviews with 84 knowledgeable tourism managers and stakeholders in 25 destinations [113].

After the literature review, the tourism and economy of many countries in the world have been severely impacted by the COVID-19 pandemic, including stakeholders in the hospitality industry, transportation industry, travel companies, the government and tourists, etc. The previous research has been extensively discussed, and there is a gap in the existing research; this paper aims to determine the decision-making criteria factors implemented by stakeholders in the tourism industry to overcome this situation, thereby providing insight for tourism to obtain a clear understanding of how to prepare for the implementation of sustainable development.

\section{Methods}

The research describes the TRIZ principal tools and the process of resolving contradictions. The DEMATEL procedure and application and measure steps are also described.

\subsection{TRIZ Principle}

The TRIZ method comes from the Russian acronym TRIZ (Teorija Rezhenija Izobretatelskikh Zadach), which translates to "Theory of Inventive Problem Solving". In 1946, the innovative and problem-solving methods created by Soviet scientist Genrich Altshuller and his team were constructed through extensive research comprising literature reviews and information analysis of more than 1 million patents worldwide [115]. The TRIZ method focuses on solving engineering and technical problems and developing innovation and technical strategies (prediction and planning), and is less used for management problems or other disciplines, such as art and culture, books and writing, process improvement, teaching, training, business models and sports [116]. After several years, TRIZ has led to the development of different tools and technologies, which are summarized as follows: 9 windows, 40 invention principles, 76 standard solutions, rules of evolution, ideality and idea results, functional analysis, effect databases, patterns of evolution, contradiction matrices, substance field resources, smart little people, and ARIZ (an algorithm for inventive problem solving) [60,117]. The TRIZ method should solve single-issue problems in engineering, manufacturing and industry. However, the social science system contains more diverse and complex problems [60]. The TRIZ method is widely accepted and has advantages in its innovative ideas and ability to provide solutions [116]. The TRIZ technical solution model analyzes reliability, repeatability and predictability to solve problems [118]. Since the establishment of the TRIZ system, its systematic approach has been able to efficiently find solutions to problems, and its application to social science problems is appropriate [60].

The TRIZ principle has been applied to an airline's problem-solving method, and the evaluation produces a framework that integrates safe operations and service quality to improve the airline's image [119]. Research in eco-innovation (environmental innovation, green innovation or sustainable innovation) showed gaps and opportunities in the field of advancement; based on the analysis framework developed, part of the construction model used ARIZ and TRIZ methods, and the model was verified [120]. The research purposes and exploration of the development of TRIZ involved various open issues related to the way of thinking, effectiveness, and tool availability of the method, research methods, 
and qualitative research that analyzes the literature review. The implementation of TRIZ has also been used in bionics, information processing, and the commercial and service industries [121].

\subsection{DEMATEL Method}

In 1973, the Battelle Association of Geneva Research Center established the DEMATEL, which is used to study complex and difficult issues, and can effectively understand the complex causal relationship structure. By examining the degree of effectiveness between the criteria factors, using matrix calculations to obtain the causal relationship and effective strength between the elements, a network relationship map such as structural equation modeling is established. DEMATEL uses matrices and related mathematical theories to calculate the causal relationship of each element, converts the relationship between the criteria factors' cause and result into the structural model of the system, and is widely used to solve various types of complex research and provide viable options and solutions for problems [60,61,122-125]. Many different techniques of the MCDM method come from literature reviews, aiming to find the significance level of the criteria factors, including AHP and ANP, but the advantage of DEMATEL is that it can examine the impact relationship map among the criteria factors [126]. With the help of these issues, the causal relationship analysis between the criteria factors can be identified $[127,128]$. Under a complex environment, the method of managing complex processes is very important. MCDM has an important role and is used by different researchers for different purposes, benefiting the solution of complex phenomena [129]. In this complex context, the DEMATEL method can provide a significant role in determining the weights of the criteria factors and formulating strategies [130]. Studies have investigated the readiness criteria factors for medical tourism in the tourism industry, and the results of using DEMATEL data analysis show the significance of various criteria factors [131]. The steps of the DEMATEL method are described as follows $[60,132,133]$. The four steps of DEMATEL are illustrated in Figure 1.

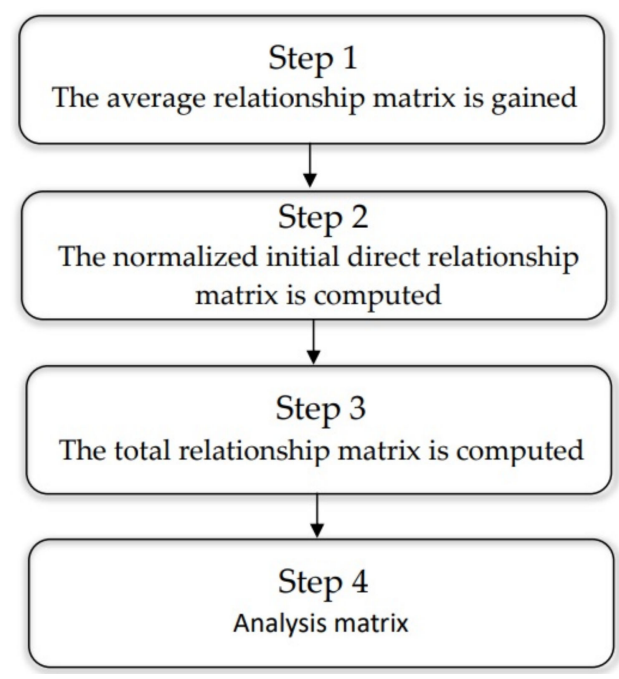

Figure 1. The four steps of DEMATEL.

Step 1. The average relationship matrix is gained.

A four-level comparison scale design is provided to measure the relationship between the principles, and then pairwise comparisons are made according to the influence and direction of the expert questionnaire between the criteria factors. Then, like the results of these evaluations, the data can be obtained as a direct relationship, e $n \times n$, is a nonnegative answer matrix, $X^{k}=\left[X_{i j}^{k}\right]$. Thus, $X^{1}, X^{2}, X^{3}, \ldots X^{m}$ are the answer matrix of each $M$ expert, each element of $X^{k}$ being an integer denoted by $X_{i j}^{k}$. The diagonal elements of each answer matrix $X^{k}$ are all set to zero. Formula (1) is used to average the scores of 
all of the expert opinions as $\mathrm{m}$. The average matrix $A=\left[a_{i j}\right]$ is denoted as the degree to which criteria factor $i$ influences criteria factor $j$.

$$
a_{i j}=\frac{1}{m} \sum_{k=1}^{m} x_{i j}^{k}
$$

Step 2. The normalized initial direct relationship matrix is computed.

By normalizing the average matrix $A$ as in Equations (2) and (3), the normalized initial direct relationship matrix $D$ is obtained.

$$
\begin{gathered}
\text { Let } z=\max \left(\max _{1 \leq i \leq n} \sum_{j=1}^{n} a_{i j}, \max _{1 \leq j \leq n} \sum_{j=1}^{n} a_{i j}\right) ; \\
\text { Then, } D=A / z
\end{gathered}
$$

Step 3. The total relationship matrix is computed.

Given that the indirect influence between the criteria factors is based on matrix power, the influence of $A$ continuously decreases. Due to the indirect influence between the criteria factors based on the power of matrix $D$, e.g., $D^{2}, D^{3}, D^{4}, \ldots, D^{\infty}$, the influence of A continues to decrease, such that it can guarantee the convergent solution of matrix inversion, such as a Markov chain matrix. $\lim _{m \rightarrow \infty} D^{m}=[0]_{n x n}$ and $\lim _{m \rightarrow \infty}\left(D+D^{2+} D^{3}+\ldots+D^{m}\right)=D(I-D)^{-1}$, where 0 is the null $n \times n$ matrix and $I$ is the $n \times n$ identity matrix. The total relationship matrix $T$ is an $n \times n$ matrix, and is defined through Equation (4).

$$
\begin{gathered}
T=\lim _{m \rightarrow \infty}\left(D+D^{2}+D^{3}+\ldots+D^{m}\right)=D(I-D)^{-1}, \text { as } m \rightarrow \infty \\
r_{i}=\left[r_{i}\right]_{n x 1}=\left[\sum_{j=1}^{n} t_{i j}\right]_{n \times 1}^{0} ; \\
c_{j}=\left\lfloor c_{j}\right\rfloor_{1 \times n}^{\prime}=\left.\left\lfloor\sum_{j=1}^{n} t_{i j}\right\rfloor\right|_{1 \times n} ^{0} ;
\end{gathered}
$$

Step 4. Analysis matrix.

$t_{i j}(i, j=1,2,3, \ldots, n)$ are denoted as criteria factors in the total relationship matrix, where $r_{i}$ and $c_{j}$ are the row sum and column sum in the total relationship matrix $T$, respectively. Through Equations (5) and (6), the sum of the rows and the sum of the columns are shaped as vectors $r_{i}$ and $c_{j}$, respectively. Then, the horizontal axis vector $\left(r_{i}+c_{j}\right)$ is made by adding $r_{i}$ to $c_{j}$. The vector is named "Prominence" to show the importance of the criteria factors. Similarly, the vertical axis $\left(r_{i}-c_{j}\right)$ is named "Relation", which can be obtained by subtracting $c_{j}$ from $r_{i}$, which can divide the criteria factors into cause-and-effect groups. In general, when $\left(r_{i}-c_{j}\right)$ is positive, the criteria factors belong to the cause group. Otherwise, if $\left(r_{i}-c_{j}\right)$ is negative, the criteria factors belong to the effect group. The cause-and-effect diagram can be obtained by mapping the data set of $\left\{\left(r_{i}+c_{j}\right),\left(r_{i}-c_{j}\right)\right\}$. This analysis can provide valuable insights for stakeholders when making decisions.

\section{Evaluating the Innovative Principles of the GMTS}

The evaluation of the GMTS is divided into three parts. First, the information on the issues that led to the contradictory system construction are summarized. Second, the innovative principles of the system are derived by adopting TRIZ heuristic reasoning. Third, these innovative principles are evaluated by adopting the expert questionnaire survey approach, which uses DEMATEL to measure the standard steps and compute the key innovation principles, such as the criteria factors and feasibility. 


\subsection{Possible Contradictions of GMTS}

Constructing the GMTS involves complex relationships among the stakeholders. The contradiction issues, as illustrated in Figure 2, are collected based on the literature review. The basis of the model is thus constructed [60].

A. The government prohibits the tourism industry under COVID-19, and the international travel contradictions are as follows:

1. The government is worried about the spread of the virus due to the flow of tourists increasing the risk of spreading the virus, so the government closes the borders to prevent the spread.

2. Travel requires tourists to go to the destination to be completed, and international travel of tourists must use transportation to reach the destination to complete the tour.

B. The contradiction between the transportation industry due to space constraints and the inability of air to flow effectively is as follows:

1. The capacity of tourist transportation is limited. Given the limited space of airplanes and cruise ships, the air cannot flow effectively of infection.

2. The cost of travel cannot be based on quantity. Therefore, increasing the space of tourists in a limited space will greatly increase the cost.

C. Travel companies need to regulate the risk of travel infections, and tourists are worried about international travel:

1. Travel company regulations increase travel costs, and travel regulations must have pandemic prevention equipment, such as masks.

2. Tourists are unwilling to increase travel costs; after various costs have increased, tourists will reduce their willingness to travel internationally.

D. Droplet infection between people in tourist hotel rooms at close range:

1. The operation of tourist hotels increases costs, and hotels cannot effectively maintain social distance due to close contact, easily spreading the virus.

2. Travel cannot be effectively controlled; the number of guest rooms in a hotel is limited. If it is divided into several hotels, the travel company cannot control it.

E. In the international pandemic outbreak, therefore, the government closed the borders and transportation vehicles could not operate effectively internationally:

1. The government has closed the borders due to the pandemic, barring tourists from international travel and preventing tourists from causing the risk of infectious diseases.

2. The transportation means cannot operate without tourists, causing transportation to stop operating and causing dilemmas.

F. In the safety structure of the hotel industry, improving the space under the pandemic is not easy, and the lack of improvement in the space distance will cause a high risk of infection:

1. The hotel industry cannot easily and effectively improve the space because of safety regulations and the construction of the structure under the government regulations.

2. There is a high risk of infection caused by the hotel's space and distance; tourism must be improved to stay safe. 


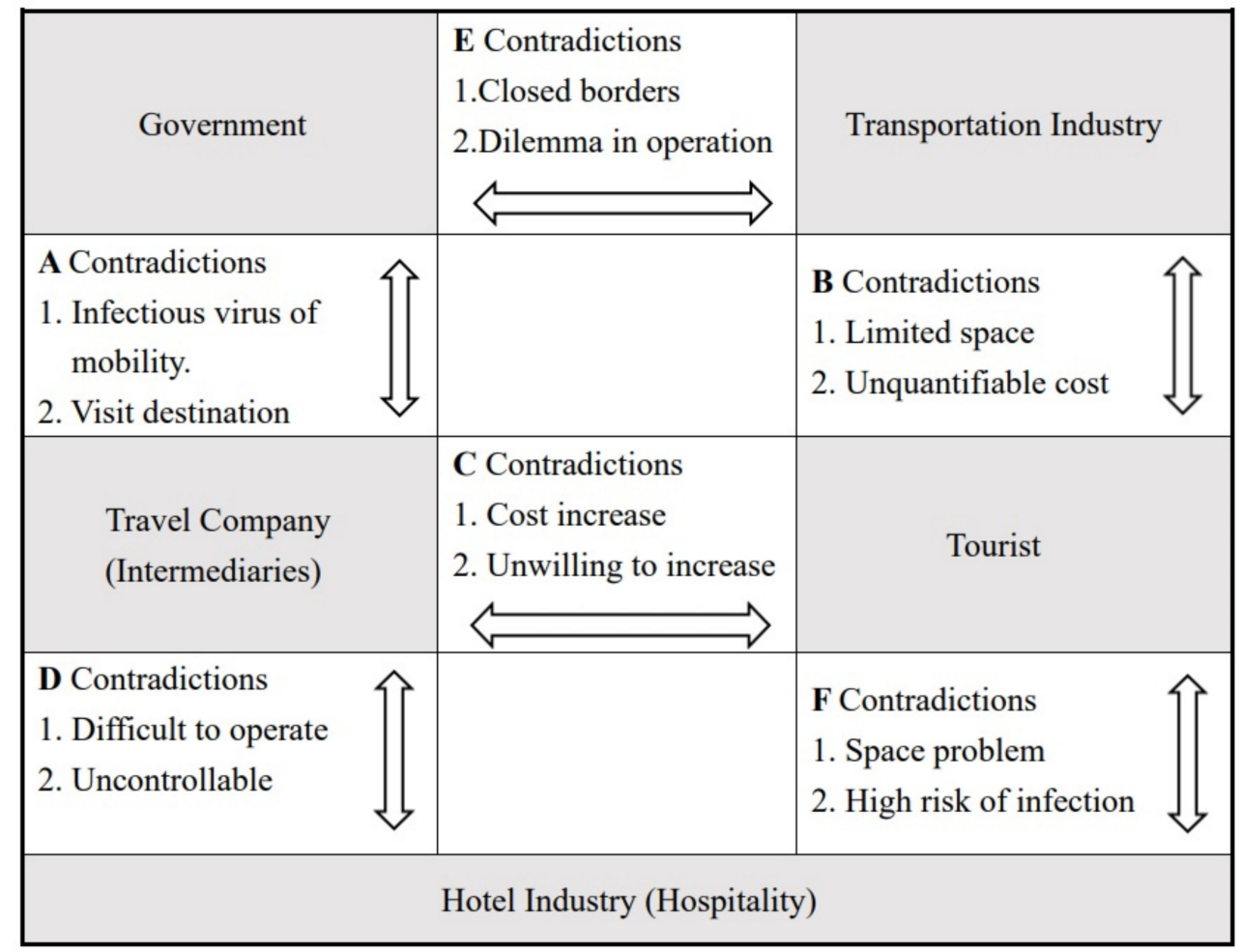

Figure 2. Issues with the GMTS. "Problems with the LTC cloud system [60]".

\subsection{Application of TRIZ Reasoning Innovation Principles}

The premise of constructing the GMTS is to use TRIZ to solve the contradictory issues of the system. COVID-19 tourism topics are innovative and transformative in paradox research because contradictions help creative and innovative thinking [11,134]. In this research, TRIZ is used to obtain innovative principles for the solution of the inherent contradictory types of GMTS. Figure 2 shows six contradictions, namely, A-F. The derivation of the six main contradictions is further described below, among which the TRIZ parameters and innovation principles are summarized in Tables 1-6. These are from Kaplan, pages $39-54[60,115]$. The principle of TRIZ is a process of solving real-world problems with heuristic reasoning. However, under the lack of a scientific basis, existing deviations in professional knowledge may cause differences or feasibility problems. The DEMATEL research method obtained from the scientific theoretical MCDM model can correct possible errors caused by human bias.

- Contradiction Relationship (A): between governments and travel companies-mobility; The infectious virus and tourist arrive at the destination to complete the tour.

The contradiction of the GMTS is that the government is worried about the spread of the virus that causes COVID-19, but travel requires tourists to go to the destination to complete the journey. Based on the contradiction matrix, the TRIZ innovation principle is obtained, and the innovation principle is obtained through the reasoning of the GMTS, A1-A4 Table 1. According to the government's anti-pandemic viewpoint, the government is worried that the mobility of international travel will cause the spread of the virus. Travel companies have cooperated with the government's policy to transform international travel into domestic travel. Although an oversupply exists, the government has proposed a plan to stimulate the tourism market to help travel companies to tide over the difficulties. According to the definition, the "undesired result" is that the contradiction parameter in the TRIZ contradiction matrix is \#15 (Duration of action of a moving object), and the parameter used to improve this feature is \#31 (Object-generated harmful factors).Corresponding to 40 innovative principles using heuristic reasoning to solve tourism in real society, the four TRIZ innovation principles contradicted by the GMTS are: (A1) under a different 
context, the government will update the tourism policy in a timely manner to achieve optimal results; (A2) transforming international travel into domestic has a positive effect; (A3) replace international travel with the expansion of on domestic homogeneous travel destinations; (A4) more travel "bubble zones" should be developed to ensure the safety of pandemic prevention.

Table 1. Innovative principles for travel companies and the government.

\begin{tabular}{|c|c|}
\hline Issues of the GMTS & $\begin{array}{l}\text { Innovative Principles Derived from Heuristic } \\
\text { Reasoning for the GMTS }\end{array}$ \\
\hline $\begin{array}{l}\text { The government is worried about the } \\
\text { spread of the virus of travel mobility } \\
\text { and travel need tourists to go to the } \\
\text { destination to complete }\end{array}$ & $\begin{array}{l}\text { (A1) Under different context, the government will } \\
\text { update the tourism policy in a timely manner to } \\
\text { achieve optimal results } \\
\text { (A2) Transforming international travel into domestic } \\
\text { has a positive effect. } \\
\text { (A3) Replace international travel with the expand on } \\
\text { domestic homogeneous travel destinations. } \\
\text { (A4) To conclude with more travel "bubble zones" to } \\
\text { ensure the safety of pandemic prevention. }\end{array}$ \\
\hline TRIZ parameters & Innovative principles derived from reasoning for TRIZ \\
\hline $\begin{array}{l}\text { Undesired Result } \\
\text { (conflict): } \\
\text { \#15Duration of action of moving object } \\
\text { \#31 Object-generated harmful factors }\end{array}$ & $\begin{array}{l}\text { \#15 Dynamicity, Optimization } \\
\text { \#22 Convert harm into benefit, Blessing in disguise } \\
\text { \#33 Homogeneity } \\
\text { \#31 Use of porous materials }\end{array}$ \\
\hline
\end{tabular}

- Contradiction Relationship (B): between the transportation industry and touristscapacity is limited and cost cannot be based on quantity.

Airplanes, cruise ships and buses in the tourism industry, as well as hotels in the hotel industry, have limited space and cannot effectively circulate risk of infection. If the space for tourists is increased, the cost will increase significantly, and the price cannot be based on quantity. According to the definition, the "undesired result" is that the contradiction parameter in the TRIZ contradiction matrix is \#23, Loss of substance, or \#8, Volume of stationary object. This item is addressed through the contradiction matrix and the TRIZ innovation principle pointed out in heuristic reasoning, as shown in B1-B4 in Table 2.

Table 2. Innovative principles for the transportation industry and tourists.

\begin{tabular}{ll}
\hline Issues of the GMTS & $\begin{array}{l}\text { Innovative Principles Derived from Heuristic } \\
\text { Reasoning for the GMTS }\end{array}$ \\
\hline & $\begin{array}{l}\text { (B1) Adjust the space separation distance in } \\
\text { transportation vehicles cabins in advance. } \\
\text { (B2) Improve the atmosphere circulation system of } \\
\text { transportation vehicles cabins. }\end{array}$ \\
$\begin{array}{l}\text { The contradiction between the } \\
\text { transportation industry due to space }\end{array}$ & $\begin{array}{l}\text { (B3) Change the density of transportation cabins } \\
\text { constraints and the inability of air to }\end{array}$ \\
$\begin{array}{l}\text { fourists. } \\
\text { flow effectively. }\end{array}$ & $\begin{array}{l}\text { (B4) Transport vehicles often use disposable } \\
\text { consumables or items that are cleaned and restored to } \\
\text { keep the cabins clean, such as alcohol disinfection or }\end{array}$ \\
& items that can mask the respiratory system. \\
\hline TRIZ parameters & Innovative principles derived from reasoning for TRIZ \\
\hline Undesired Result & \#10 Prior action \\
(conflict): & \#39 Inert environment or atmosphere \\
\#23 Loss of substance & \#35 parameter change, changing Properties \\
\#8 Volume of stationary object & \#34 Rejection and regeneration, Discarding \\
& andrecovering \\
\hline
\end{tabular}


- Contradiction Relationship (C): between travel companies and tourists-the travel company regulates the increase in travel costs, and the tourists are unwilling to increase travel expenditures.

Table 3. Innovative principles for travel companies and tourists.

\begin{tabular}{ll}
\hline Issues of the GMTS & $\begin{array}{l}\text { Innovative Principles Derived from Heuristic } \\
\text { Reasoning for the GMTS }\end{array}$ \\
\hline & (C1) The travel company arranges various \\
travel-related matters such as cabin interior, and must \\
identify the safety of preventing diseases. \\
(C2) Travel companies arranging travel-related matters \\
must identify the operational procedures to eliminate \\
the risk of infection in advance and make them \\
regulates the increase in travel costs & available to tourist inspection. \\
and the tourist travel costs are & (C3) The travel company should compulsorily obtain a \\
unwilling to increase & health quarantine certificate for each tourist each time \\
expenditures. & when performing international travel to prevent \\
& infectious diseases. \\
& (C4) In this COVID-19 pandemic, travel companies \\
& can improve the overall quality and value of travel. \\
\hline TRIZ parameters & Innovative principles derived from reasoning for TRIZ \\
\hline Undesired Result & \#35 parameter change, changing Properties \\
(conflict): & \#10 Prior action \\
\#35 Adaptability orversatility & \#28. Replacement of a mechanical system with fields \\
\#36 Device complexity & \#29 Pneumatics or hydraulics \\
\hline
\end{tabular}

In a pandemic, travel companies must pay more for the related costs of tourist equipment and budget in the travel regulations to prevent tourists from becoming infected due to international travel. However, because the number of tourists continues to increase various travel costs, such as air ticket fares, hotel rates and insurance costs, tourists have reduced their willingness to travel internationally and encounter conflicts. According to the definition, the "undesired result" is that the contradiction parameters in the TRIZ contradiction matrix are \#35, Adaptability or versatility, and \#36, Device complexity. This item is addressed through the contradiction matrix and the TRIZ innovation principle pointed out in the heuristic reasoning, as shown in C1-C4 in Table 3.

- Contradiction Relationship (D): between travel companies and the hospitality industry - the increased cost of tourist hotel operation and the ineffective control of the travel company. 
Table 4. Innovative principles for travel companies and the hospitality industry.

\begin{tabular}{|c|c|}
\hline Issues of the GMTS & $\begin{array}{l}\text { Innovative Principles Derived from Heuristic } \\
\text { Reasoning for the GMTS }\end{array}$ \\
\hline $\begin{array}{l}\text { The increased cost of tourist hotel } \\
\text { operation and the } \\
\text { ineffective control of tourism. }\end{array}$ & $\begin{array}{l}\text { (D1) The volume density of hotel cabins must be } \\
\text { adjustedaccording to the characteristics of tourist and } \\
\text { the tourist numbers. } \\
\text { (D2) Travel companies should establish contact } \\
\text { groupsduring each trip to increase contact frequency } \\
\text { and effective control. } \\
\text { (D3) The hotel industry obtains tourist information } \\
\text { andquarantine certificates in advance when } \\
\text { administer accommodation business to prevent } \\
\text { infectious diseases. } \\
\text { (D4) In context of infectious diseases, travel companies } \\
\text { and the hotel industry have advanced the concept of a } \\
\text { singleprevention room, which reverses the traditional } \\
\text { concept of a two-person travel room. }\end{array}$ \\
\hline TRIZ parameters & Innovative principles derived from reasoning for TRIZ \\
\hline $\begin{array}{l}\text { Undesired Result } \\
\text { (conflict): } \\
\text { \#37Difficulty of } \\
\text { detecting and } \\
\text { measuring } \\
\text { \#23 Loss of substance }\end{array}$ & $\begin{array}{l}\text { \#35parameter change, changing Properties } \\
\text { \#18 Mechanical vibration/oscillation } \\
\text { \#10 Prior action } \\
\text { \#13 Inversion, the other way around }\end{array}$ \\
\hline
\end{tabular}

After the outbreak of the pandemic, droplets spread from people to people in various regions, especially at close distances. The hotel industry was greatly affected. Hotels cannot effectively maintain social distance due to space factors. Therefore, the number of guest rooms in hotels is limited. If maintaining social distancing and staying in other hotels separately are desired, travel companies will not be able to effectively control the tourist situation. According to the definition, the "undesired result" is that the contradiction parameter in the TRIZ contradiction matrix is \# 37, Difficulty of detecting and measuring, and \#23, Loss of substance. This item is addressed through the contradiction matrix and the TRIZ innovation principle pointed out in heuristic reasoning, as shown in D1-D4 in Table 4.

- Contradiction Relationship (E): between the government and the transportation industry -in the international pandemic outbreak, the government closed the borders, and transportation vehicles could not operate effectively internationally.

In the global pandemic, governments of various countries and regions closed their borders to avoid the risk of infectious diseases. Airplanes, cruise ships and buses in various places have completely ceased operations, and the transportation industry has suffered serious closures. According to the definition, the "undesired result" is that the contradiction parameter in the TRIZ contradiction matrix is \#11, Stress or pressure, and \# 26, Quantity of substance. This item is addressed through the contradiction matrix and the TRIZ innovation principle pointed out in the heuristic reasoning, as shown in E1-E3 in Table 5. 
Table 5. Innovative principles for the government and the transportation industry.

\begin{tabular}{ll}
\hline Issues of the GMTS & $\begin{array}{l}\text { Innovative Principles Derived from Heuristic } \\
\text { Reasoning for the GMTS }\end{array}$ \\
\hline $\begin{array}{l}\text { The international pandemic outbreak, } \\
\text { therefore, the } \\
\text { government closed the borders and the }\end{array}$ & $\begin{array}{l}\text { (E1) Change the structural quality of the } \\
\text { transportationsystem and effectively prevent disease } \\
\text { infection. }\end{array}$ \\
$\begin{array}{l}\text { (E2) The design of the transportation vehicle cabin was } \\
\text { changed, and the space replaced the straight line with } \\
\text { internationally. }\end{array}$ & $\begin{array}{l}\text { the curve, and the curved surface replaced the plane. } \\
\text { (E3) Take advantage of the occurrence of the pandemic }\end{array}$ \\
to quickly change the Overall pandemic prevention \\
structure of transportation vehicles.
\end{tabular}

- Contradiction Relationship (F): between tourists and the hotel industry-the safety structure of the hotel industry introduces difficulties in improving the space during the pandemic, and the lack of improvement in the space distance will cause a high risk of infection.

The structure of the government-managed hotel industry is significant in its construction regulations, and hotels cannot arbitrarily change their building structure; the inability to improve the space distance immediately will effectively lead to a high risk of infection. The hotel's space and distance introduce a high risk of infection, and the reduction in hotel accommodation rates has caused problems. This conflict has caused a dilemma in the hotel industry. According to the definition, the "undesired result" is that the contradiction parameters in the TRIZ contradiction matrix are \#6, Area of moving object, and \#31, Objectgenerated harmful factors. This item is addressed through the contradiction matrix and the TRIZ innovation principle pointed out in the heuristic reasoning, as shown in F1-F3 in Table 6.

Table 6. Innovative principles for tourists and the hotel industry.

\begin{tabular}{|c|c|}
\hline Issues of the GMTS & $\begin{array}{l}\text { Innovative Principles Derived from Heuristic } \\
\text { Reasoning for the GMTS }\end{array}$ \\
\hline $\begin{array}{l}\text { The safety structure of the hotel } \\
\text { industry is not easy to improve the } \\
\text { space under the pandemic, and the lack } \\
\text { of improvement in the space distance } \\
\text { will cause high risk of infection. }\end{array}$ & $\begin{array}{l}\text { (F1) Without damage to the structure, it is effectively } \\
\text { divided into separate tourist hotel rooms to prevent } \\
\text { infection. } \\
\text { (F2) Convert harm into benefit. The space saved in the } \\
\text { hotel will be added to useful facilities for tourists, such } \\
\text { as independent reading rooms. } \\
\text { (F3) Change the hotel space to use composite materials } \\
\text { to prepare for appropriate adjustments at any time. }\end{array}$ \\
\hline TRIZ parameters & Innovative principles derived from reasoning for TRIZ \\
\hline $\begin{array}{l}\text { Undesired Result } \\
\text { (conflict): } \\
\text { \#6 Area of moving object } \\
\text { \#31Object-generatedharmful factors }\end{array}$ & $\begin{array}{l}\text { \#1 Segmentation } \\
\text { \#22 Convert harm into benefit } \\
\text { \#40 Composite materials }\end{array}$ \\
\hline
\end{tabular}

\subsection{Evaluating DEMATEL Innovation Principles}

Through the invented reasoning method in TRIZ heuristics, innovative principles and criteria factors have been derived from the contradiction between COVID-19 and stakeholders in the tourism industry. Simultaneously, it must be ranked against these 
innovative principles. In this research, steps will be provided to analyze the relationship among the key principles of the DEMATEL method.

Step 1. DEMATEL expert questionnaire design and proposition

Using the DEMATEL method to assess the relationship among stakeholders in the complex tourism industry is appropriate. The innovative principles and criteria factors derived from TRIZ heuristic reasoning are converted, and the propositions are in the DEMATEL questionnaire format. In the questionnaire, experts are required to choose scores of $0,1,2,3$, or 4 , which indicate the degree of influence. Here, 0 represents no influence, 1 represents low influence, 2 represents medium influence, 3 represents high influence, and 4 represents extremely high influence.

Step 2. Questionnaire survey of tourism stakeholders and experts

During the pilot test of the questionnaire in this study, we invited two researchers, professors, and associate researchers from academic research universities. They participated in the pre-test and confirmed the appropriateness of the questionnaire's propositions and term explanations. For the formal questionnaire, we invited two tourism experts from government officers, three experts from travel companies, three experts from the transportation industry, three experts from the hotel industry and two experts from the university tourism field to conduct the DEMATEL survey. A total of 15 experts were invited, with an average seniority of 27 years.

Step 3. Compute and analyze DEMATEL

The official questionnaire was completed between December 2020 and February 2021. Due to the COVID-19 pandemic, borders and travel bans, all countries and regions are still closed, and tourism stakeholders' industries are in a period of vulnerability. The 13 complete expert questionnaires were conducted over three months. The valid questionnaires were analyzed by referring to the DEMATEL method.

Step 4. DEMATEL causal diagram analysis results

The study obtained 11 criteria factor scales based on the TRIZ invention principle. Following the four-score survey results of the expert questionnaire, DEMATEL was used to compute the causal relationship among various criteria factors, and a diagram was constructed to explain the significance of the criteria factors. The DEMATEL data were integrated with cause-and-effect diagrams to produce quantitative objective analysis, which proves the contribution of this research.

\section{Results}

\subsection{General Analysis of DEMATEL}

In this research, the expert questionnaire of innovation principles obtained by tourism stakeholders in TRIZ heuristic reasoning adopted DEMATEL matrix analysis to obtain the results to construct the GMTS aspect. This questionnaire was derived from the tourism industry. Experts in the stakeholder industry, comprising five organizations-namely, the government, tourism companies, the transportation industry, the hotel industry, and universities-were invited. A total of two pre-test questionnaires and 13 formal expert questionnaires were individually administered through the survey, based on the experts professional experience evaluation and knowledge related to TRIZ's problem-solving to prove the validity of expert evaluation. Table 7 provides details. 
Table 7. Background of the experts.

\begin{tabular}{|c|c|c|c|}
\hline Stakeholders & No & Experts Organizations/Title & Seniority \\
\hline Pilot & 1 & National Central University/professor & 35 \\
\hline Questionnaire & 2 & Feng Chia University/associate researcher & 26 \\
\hline \multirow[t]{2}{*}{ Government } & 3 & $\begin{array}{l}\text { Tourism Bureau, Republic of China (Taiwan)/ } \\
\text { deputy director }\end{array}$ & 17 \\
\hline & 4 & Taoyuan City Government/deputy district chief & 15 \\
\hline \multirow{3}{*}{$\begin{array}{l}\text { Travel } \\
\text { Company }\end{array}$} & 5 & Poa International Travel Agent/general manager & 30 \\
\hline & 6 & Hsi Hung Travel Service Co. Ltd./director & 30 \\
\hline & 7 & Grandee Express Crop/chairman & 40 \\
\hline \multirow{3}{*}{$\begin{array}{l}\text { Transportation } \\
\text { Industry }\end{array}$} & 8 & EVA Airways Corporation/director & 26 \\
\hline & 9 & $\begin{array}{l}\text { Overseas Travel Service (Airlines \& Cruises } \\
\text { GSA)/general manager }\end{array}$ & 20 \\
\hline & 10 & Chinese Maritime Transport Ltd./senior manager & 46 \\
\hline \multirow{3}{*}{$\begin{array}{l}\text { Hotel } \\
\text { (Hospitality) } \\
\text { Industry }\end{array}$} & 11 & $\begin{array}{l}\text { Shangri-La's Far Eastern Plaza Hotel Taipei/ } \\
\text { manager }\end{array}$ & 14 \\
\hline & 12 & Le Méridien Taipei/supervisor & 10 \\
\hline & 13 & Sunworld Dynasty Hotel Taipei/manager & 33 \\
\hline \multirow{2}{*}{$\begin{array}{l}\text { Academic } \\
\text { University }\end{array}$} & 14 & $\begin{array}{l}\text { Tungnan University Tourism Department } \\
\text { /associate professor }\end{array}$ & 30 \\
\hline & 15 & $\begin{array}{l}\text { Ming Chuan University Tourism field } \\
\text { /assistant professor }\end{array}$ & 35 \\
\hline
\end{tabular}

According to the expert questionnaire, the DEMATEL formula was used to compute the causal relationship among the various criteria factors of the influence matrix; see Table A1 (in Appendix A).

Three steps were used to analyze the DEMATEL results. First, we computed the total relationship matrix based on the results of the expert questionnaire. Second, as shown in Table 8 , we computed the significance of the criteria factors $(\mathrm{ri}+\mathrm{cj})$ and $(\mathrm{ri}-\mathrm{cj})$ based on the total relationship matrix. ( $\mathrm{ri}+\mathrm{cj})$ and $(\mathrm{ri}-\mathrm{cj})$ were used as the coordinates to construct the causal diagram. Third, in order to obtain the key influence criteria factors, this study set the threshold value as the standard deviation plus the average value to adjust it appropriately $[60,135]$.

Table 8. The significance of the criteria factors.

\begin{tabular}{lcccc}
\hline \multicolumn{1}{c}{ Criteria Factors } & $\mathbf{r i}$ & $\mathbf{c j}$ & $\mathbf{r i} \mathbf{c j}$ & $\mathbf{r i}-\mathbf{c j}$ \\
\hline A1 Optimization Policy & 6.994 & 7.212 & 14.207 & -0.218 \\
A2 Conversion Policy & 7.531 & 7.128 & 14.659 & 0.404 \\
A3 Internationalization Strategy & 6.811 & 7.005 & 13.816 & -0.195 \\
A4 Quality Management & 7.514 & 6.228 & 13.742 & 1.287 \\
B1 Distance Control & 6.218 & 6.455 & 12.673 & -0.236 \\
B2 System Management & 6.559 & 6.448 & 13.007 & 0.111 \\
B3 Humanized Management & 6.532 & 6.800 & 13.332 & -0.268 \\
B4 Cleaning Management & 6.936 & 7.164 & 14.100 & -0.228 \\
C1 Tourism Regulations & 7.081 & 6.973 & 14.053 & 0.108 \\
C2 Transparency Strategy & 6.852 & 6.951 & 13.803 & -0.099 \\
C3 Mandatory Policy & 6.800 & 6.884 & 13.684 & -0.084 \\
C4 Upgrade Strategy & 6.230 & 6.414 & 12.644 & -0.184 \\
D1 Space Management & 6.507 & 7.147 & 13.653 & -0.640 \\
D2 Security Control & 6.377 & 13.617 & 19.994 & -7.241 \\
D3 Hotel Regulations & 6.520 & 6.769 & 13.289 & -0.248 \\
D4 Health Management & 5.045 & 6.268 & 11.313 & -1.223 \\
E1 Structure Management & 6.456 & 6.237 & 12.694 & 0.219 \\
\hline
\end{tabular}


Table 8. Cont.

\begin{tabular}{lcccc}
\hline \multicolumn{1}{c}{ Criteria Factors } & ri & $\mathbf{c j}$ & $\mathbf{r i}+\mathbf{c j}$ & $\mathbf{r i}-\mathbf{c j}$ \\
\hline E2 Space Design & 6.144 & 5.443 & 11.587 & 0.702 \\
E3 Structure Preparation & 6.140 & 6.174 & 12.314 & -0.035 \\
F1 Guest Room Management & 6.446 & 6.428 & 12.874 & 0.018 \\
F2 Hotel facilities Management & 6.038 & 5.643 & 11.681 & 0.394 \\
F3 Hotel Material Preparation & 6.431 & 5.921 & 12.352 & 0.511 \\
\hline
\end{tabular}

The total relationship matrix was used to select the threshold value. Below the threshold value, the value is considered to have the least impact on the relationship, and can therefore be ignored. This finding helps to clearly show the causal relationship among the criteria factors. The key influence threshold value of this study was set as the standard deviation plus the average value, with 0.344 as the standard. This determined 11 important criteria factors. According to the $11 \times 11$ matrix of the expert questionnaire, which was then computed by DEMATEL, the results were A2 $>\mathrm{A} 1>\mathrm{B} 4>\mathrm{C} 1>\mathrm{A} 3>\mathrm{C} 2>\mathrm{A} 4>\mathrm{C} 3>$ D1 > B3 > D3, as shown in Table 9.

Table 9. The value above the threshold of the criteria factors.

\begin{tabular}{lcccc}
\hline \multicolumn{1}{c}{ Criteria Factors } & $\mathbf{r i}$ & $\mathbf{c j}$ & $\mathbf{r i}+\mathbf{c j}$ & $\mathbf{r i} \mathbf{- c j}$ \\
\hline A1 Optimization Policy & 6.994 & 7.212 & 14.207 & -0.218 \\
A2 Conversion Policy & 7.531 & 7.128 & 14.659 & 0.404 \\
A3 Internationalization Strategy & 6.811 & 7.005 & 13.816 & -0.195 \\
A4 Quality Management & 7.514 & 6.228 & 13.742 & 1.287 \\
B3 Humanized Management & 6.532 & 6.800 & 13.332 & -0.268 \\
B4 Cleaning Management & 6.936 & 7.164 & 14.100 & -0.228 \\
C1 Tourism Regulations & 7.081 & 6.973 & 14.053 & 0.108 \\
C2 Transparency Strategy & 6.852 & 6.951 & 13.803 & -0.099 \\
C3 Mandatory Policy & 6.800 & 6.884 & 13.684 & -0.084 \\
D1 Space Management & 6.507 & 7.147 & 13.653 & -0.640 \\
D3 Hotel Regulations & 6.520 & 6.769 & 13.289 & -0.248 \\
\hline
\end{tabular}

\subsection{Causal Diagram}

The value above the threshold was used to draw the causal diagram in Figure 3. By subtracting cj from ri, the vertical axis (ri - cj) named "relationship" can be obtained, which can be identified as the cause group in Figure 3. 


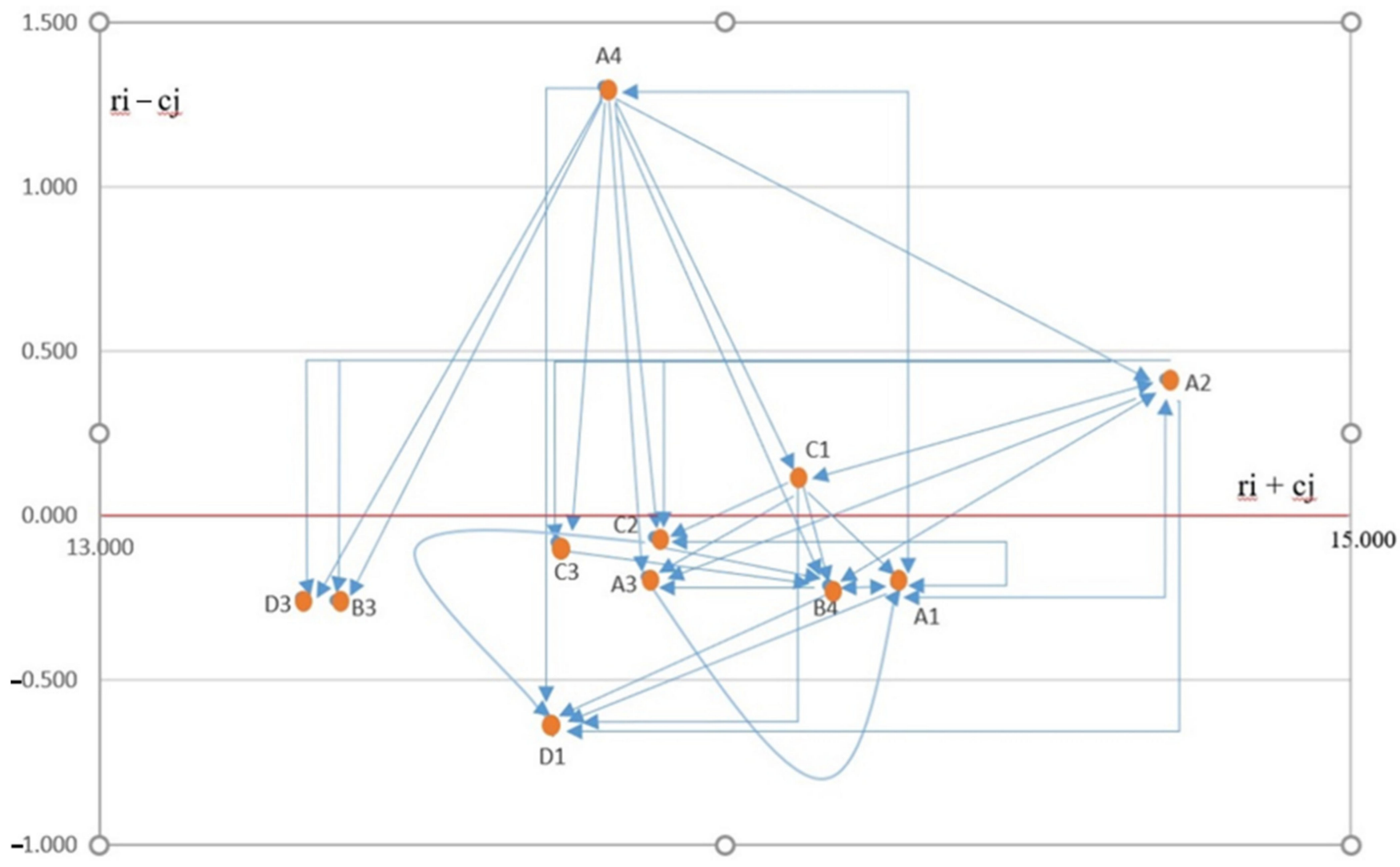

Figure 3. Causal Diagram. If $(\mathrm{ri}-\mathrm{cj})$ is negative, the criteria factors are grouped into effect groups. The findings indicate that the causal diagram is described as follows. The evaluation criteria factors include the conversion policy (A2), quality management (A4) and tourism regulations (C1) as the criteria factors cause group. The optimization policy (A1), internationalization strategy (A3), humanized management (B3), cleaning management (B4), transparency strategy (C2), mandatory policy (C3), space management (D1) and hotel regulations (D3) are the criteria factor effect groups.

\subsection{Cause Group Analysis of the Criteria Factors}

After we adopted the DEMATEL matrix analysis, the resulting causality affected the GMTS criteria factors. However, their performance may affect the overall goal and direction. The criteria factors in the cause group should attract more attention. In the causal diagram (Figure 3), the single-headed arrows represent the direction of the effect of the criteria factors on others; the double-headed arrows represent effects in both directions. For example, (A4) directly affects (A2, A3, B3, B4, C1, C2, C3, D1, D3) and is mutually affected by $\mathrm{A} 1$ among all of the criteria factors in the cause category. The highest quality management (A4) had an (ri - cj) score of 1.287 , meaning that A4 has a greater impact on the entire GMTS. In addition, Table 9 shows that, among all of the causal relationships, the influence ci of A4 is 7.514, ranking in the top two. Therefore, A4 has a significant impact on the other criteria factors. Generally, A4 is the main criteria factor that has attracted more attention in the theory and practice of GMTS. The second is (C1), of which the (ri + cj) score of 14.053 is a very high score among all of the GMTS criteria factors, and of which the (ri cj) score of 0.108 is positive, affecting the other criteria factors. Finally, in (A2), the (ri - cj) score is positive, showing that A2 is also a causal criteria factor of the GMTS. However, its $(\mathrm{ri}+\mathrm{cj})$ score of 14.659 is the highest among all of the GMTS criteria factors. A2's ability to improve the GMTS, according to ri is 7.531 score and cj is 7.128 score, it has a high impact on other criteria factors. 


\subsection{Effect Group Analysis of the Criteria Factors}

The criteria factors in the effect group are often susceptible to the influence of other criteria factors, making the effect criteria factors unsuitable as key success criteria factors. Nevertheless, discussing the effect criteria factors is still necessary to find out the feature of each criteria factor. (D1) ( $\mathrm{ri}+\mathrm{cj})$ ranks second at the end, indicating that it is an easily affected criteria factor in the meaning of the GMTS. Furthermore, the score of $(\mathrm{ri}-\mathrm{cj})$ of (D1) is -0.640 , which is the minimum value among the impact criteria factors. In order to further explain this phenomenon, the influence degree $(\mathrm{ri}+\mathrm{cj})$ is13.653. The influencing criteria factors are relatively small, meaning that (D1) is one of the most easily affected criteria factors (Figure 3), and obviously will affect other criteria factors and the GMTS. In the causality diagram, (C2) is the effect criteria factor, and (ri - cj) is -0.099 , which is slightly lower than zero. This finding shows that (C2) is only slightly affected by other criteria factors and has a considerable impact on the GMTS. (C2) (ri + cj) is 13.803 as the intermediate score, which can be marked as an impact standard basis. The (A1) (ri + cj) score of 14.207 ranks second and the (B4) 14.100 score of 14.100 ranks third, but because the $(\mathrm{ri}-\mathrm{cj})$ scores are negative, improvement is needed. However, these results have little effect on GMTS. The same applies for (A3), (C3), (D3) and (B3).

\section{Discussion}

This study selected the threshold value through the total relationship matrix. A value higher than the threshold value is considered to have the greatest impact on the relationship. In total, 11 criteria factors were adopted to improve the construction of the GMTS. According to the analysis results, several management implications were derived. Owing to its impact on the effect group criteria factors, the cause group criteria factors must be focused on in advance [136]. Past studies have shown that the cause group criteria factors are difficult to implement, while the effect group criteria factors are easy to implement [137]. Furthermore, the criteria factors in the effect group are easily affected by other criteria factors, and predicting the impact on other criteria factors when they are implemented is difficult, resulting in further difficulties in implementation.

The study found that when constructing the GMTS, the focus was on the four criteria factors of quality management (A4), conversion policy (A2), transparency strategy (C2), and space management (D1). After analyzing and drawing the causal diagram, (A4) was the cause group. When implementing tourism quality management, government departments only interact with the optimization policy (A1). Simultaneously, (A1) affected all criteria factors and was not affected by other criteria factors. It was regarded as the first significant criteria factor to implement GMTS. (A2) was the cause group, namely, the implementation of the government unit transformation policy, and (A1, B4 and C1) interact with each other, which can be regarded as the second criteria factor in the implementation of the criteria factors. (C2) was the effect group, namely, the intermediate value of the transparency strategy of the travel company among the 11 criteria factors, indicating that (C2) was the basic criteria factor in the entire GMTS. (D1) was the effect group; the space management of travel companies and the hotel industry were also the criteria factors that were most affected when the GMTS was executed. The results analysis showed that the improvement effect criteria factors group (A1, A3, B3, B4, C2, C3, D1, D3) and the cause criteria factors group (A2, A4, C1) can reach the effect criteria factors. In terms of the DEMATEL data computed, the (A2) conversion strategy was the most important criteria factor affecting GMTS. However, in the causality diagram (A4), quality management was the least affected by other criteria factors when the GMTS was constructed, meaning that the government's quality management will not be affected by other criteria factors. This research quality management means "to conclude with more travel bubble zones", which was the first GMTS criteria factor considered. The "travel bubble" enables tourists to travel to allied countries without quarantine, reducing the risk of travel to destinations [82]. Furthermore, it was proven that the government's conversion policy (A2) and tourism regulations ( $\mathrm{C} 1$ ) are of almost the equal importance. The losses and recovery caused by the 
pandemic require government assistance $[10,82,97,98,104,138]$. This echoes past research. The causal diagram shows that the optimization policy (A1), cleaning management (B4), and space management (D1) were in the effect group. The three criteria factors were the most susceptible to the impact of each criteria factor; indeed, these three criteria factors were not difficult to implement. A problem arises when the implementation of the other criteria factors are changed under the context, and these three criteria factors were also affected. They were the most vulnerable part of the GMTS. The three criteria factors of mandatory policy (C3), humanized management (B3) and hotel regulations (D3) were in the effect group, and were not the primary criteria factors to be implemented. However, the other criteria factors have little impact on these three criteria factors, it was a relatively stable criteria factors in the implementation of GMTS. Finally, internationalization strategy (A3) was in the effect group, which does not considerably affect other criteria factors, nor was it the criteria factors that was mainly affected. (A3) can be regarded as a criteria factors that was implemented later.

\subsection{Implications for Research}

This study is the first to extend TRIZ principles and two DEMATEL methods to construct a GMTS; 15 experts participated in the research, there were 13 experts' questionnaires, and they examined the decision-making criteria factors implemented by tourism stakeholders to address the issues of the pandemic crisis. Decision makers can evaluate the sustainable development of their industry; that is, stakeholders can use GMTS to solve the dilemma when the crisis affects the tourism industry. This innovative model is the first time that it has been applied to the crisis of the tourism industry, and it contributes to the academic literature. Kock and Assaf [56] aimed to advocate for the originality of tourism research. They hoped that tourism scholars would propose an innovative and creative transformation process for the tourism industry [57]. Previous research discussed crisis decision-making regarding tourism, international tourism product decisions [47], tourists' decision-making on tourist destinations [26], tourism risk perception and tourists' decision-making behavior [50] and hotel room rate decision-making [69]. However, research discussing a gap model of decision-making is lacking. Our findings are that the government's decision-making to establish "bubble zones" in quality management (A4) and the travel companies to promote products in "bubble zones" destinations can improve the problem of stakeholders under the impact of the COVID-19 pandemic. In Hong Kong, China, the "travel bubble" plan allows tourists to travel to the country without quarantine, and the relationship between the destination of the COVID-19 pandemic "travel bubble" and travel intent has been investigated [82]. In Ho Chi Minh City, Vietnam, qualitative and quantitative methods were used to discuss and study the human-machine interactive (HMI) technologies and the psychological factors in the "bubble zones" of tourist destinations [53]. In the Pacific, this is a commentary article; the COVID-19 pandemic has caused travel restrictions, and the economies of these 22 countries have been severely hit; as Australia and New Zealand are effectively managing COVID-19, the "bubble" plan may allow the tourism that many countries depend on to begin flowing again [139]. The previous discussion was on the tourism "bubble zones" and the tourism industry. This study aimed to provide GMTS to address this issue; tourism stakeholders will establish the new GMTS to solve the dilemma under the influence of COVID-19. In addition, it was also found that conversion policy (A2) and tourism regulations (C1) are criteria factors that need to be improved. However, when the two criteria factors are immediately improved, other criteria factors will be affected simultaneously, and the degree of improvement will be weakened. The two criteria factors are necessary for future improvement. This article has developed new insights on COVID-19 and tourism stakeholders to bridge the gap in the literature. 


\subsection{Implications for Practice}

The government must solve the dilemma of the tourism industry under the pandemic situation, and its most important task is to conduct the effective quality management (A4) of the tourism "bubble zones". The health and safety strategy of travel companies, the management of space density in the transportation industry, and the distance and equipment integration of the hotel industry all require government policy support and implementation. These improvement processes should not incur excessive expenses for tourists. Therefore, the government can make decisions to improve the issues affecting tourism in the pandemic. Travel companies are the most important operators in arranging travel groups, and as stakeholders in the tourism industry, they are the travel intermediaries planning the tour itinerary for tourists. Travel companies must propose a set of management regulations for the health and safety of tourists. Such regulations include transparent travel health and safety instructions, discussing the timely adjustment of cabin space in the transportation industry, introducing effective hotel equipment pandemic prevention concepts, cooperating with government policies to plan travel quality management strategies suitable for tourists, and implementing quality management. These steps can achieve sustainable conditions for stakeholders in the tourism industry under the pandemic.

In the past, there have been many and huge crises in the tourism industry, and when the stakeholders of the tourism industry face every crisis, they can only passively respond to the impact of the crisis and wait for the crisis to pass to restart the mechanism of tourism. However, this COVID is different from the previous crisis. Nature magazine stated that "the virus cannot be completely eradicated within a few years" [140].

In practice, the transportation industry and hospitality industry are unable to immediately improve the space and density of cabins due to legal safety regulations and structural regulations. Travel companies are constrained by the transportation industry and the hospitality industry, and cannot propose methods to implement safe behaviors. Increasing travel costs are not what the tourists expect. The government is unable to propose effective compulsory regulations, and tourism stakeholders will face a significant impact during the pandemic crisis. In this study, a GMTS method was constructed, and a decision-making model that can solve the problem of the stakeholders in the tourism industry was proposed. The TRIZ principle and the DEMATEL method were adopted to analyze the most important quality management (A4) criteria factors for improvement, providing practical insights. The criteria factors in decision-making in the event of a crisis in the tourism industry can solve the crisis problem. It further suggested criteria factors for the improvement of tourism-related industries for the purpose of sustainable development of the industry.

\section{Conclusions and Contribution}

\subsection{Conclusions}

Tourism has become one of the most important industries in the world. Tourism has also caused disasters and crises such as viruses and infectious diseases due to tourist mobility. It affects economic benefits, employment opportunities and international exchanges. These effects have become more and more important. Many discussions have been held about the COVID-19 pandemic, and extensive debates have been conducted in academic research. However, the modeling constructions of stakeholders in the tourism industry have rarely been studied. To the best of our knowledge, this paper is the first to adopt TRIZ and DEMAEL methods to study this phenomenon. The COVID-19 pandemic is an ideal test-bed for this study, and this research will drive useful implications for stakeholders in the tourism industry.

This study surveyed the contradictions and conflicts among stakeholders of the tourism industry, such as the government, travel companies, the transportation industry and the hospitality industry in the COVID-19 pandemic, and established the criteria factors for the implementation of a GMTS. The study constructed a 22-item relationship matrix under the heuristic reasoning of the TRIZ invention principle. After analysis by DEMATEL 
to obtain the key impact criteria factors, the threshold value was adjusted appropriately to obtain 11 important relationship criteria factors, a new model was constructed and the key criteria factors were determined. The value of the model was confirmed in the survey. The three most important criteria factors of the DEMATEL matrix were computed and the data were analyzed, and that significantly affected the criteria factors in the decision-making.

The three criteria factors of the conversion policy (A2), optimization policy (A1), and cleaning management (B4) were the most important criteria factors for the GMTS to make immediate decisions in this study. In other words, when the tourism industry is affected by a pandemic, the stakeholders of the tourism industry will produce significant criteria factors in the decision. However, another indicator that is more important is the criteria factors relationship. When the cause group is a positive number, the higher the relationship, the higher the degree of importance, and the higher the willingness to improve these criteria factors. Simultaneously, when the effect group is a negative number, this represents the criteria factors that are affected. Therefore, no space is available for improvement in the comparison of these criteria factors. The criteria factor of the conversion policy (A2) has the highest importance, followed by quality management (A4) and tourism regulations (C1).

In addition to the matrix analysis, the direction of the arrows in the causal diagram implies important management implications. The causal diagram in Figure 3 indicates that the quality management (A4) arrows point to 10 criteria factors, which are only with the optimization policy (A1). The double arrows indicate that they influence each other, meaning that quality management will not be affected by the 10 relationship criteria factors when implementing GMTS decision-making, resulting in the most significant improvement effect. Second, the conversion policy's (A2) single arrow affects internationalization strategy (A3), humanized management (B3), transparency strategy (C2), mandatory policy (C3), space management (D1) and hotel regulations (D3). Double arrows indicate that tourism regulations (C1), cleaning management (B4) and optimization policy (A1) influence each other. If quality management (A4) is used as a decision-making improvement, it will affect the relationships of the six criteria factors, but the influence of a criteria factor may weaken the degree of improvement under the two-way influence, and the improvement effect cannot be evaluated. Finally, tourism regulations' (C1) single-arrow affects optimization policy (A1), cleaning management (B4), space management (D1), internationalization strategy (A3) and transparency strategy (C2). Double arrows indicate that the criteria factors affect each other with conversion policy (A2). Quality management (A4) will affect five criteria factors, but it will also be affected by two criteria factors, and the improvement effect is limited. This study indicates that quality management (A4) is the most important decision-making criteria factor for stakeholders in the tourism industry; quality management is found in the relationship between the government and travel companies. This study clarified the degree of influence of key criteria factors and the causal relationship among many complex criteria factors, and determined the most important criteria factors. This finding is a significant outcome of this research.

This research background in Taiwan adopted TRIZ principles and DEMATEL methods to construct a GMTS, which solved the tourism industry decision-making problem under COVID-19. We solved three problems. First, this research provided a new model GMTS to solve the issues of tourism stakeholders. Second, the research identified the decision-making criteria factors implemented by tourism stakeholders, quality management, conversion policies and tourism regulations that decision-makers can use to evaluate their industry's approach to sustainable development. Finally, it examined the criteria factor implementation perspective. Travel "bubble zones" that ensure both "safety and quality" were concluded upon under government policies in countries and regions of the world. Furthermore, the tourism industry is responsible for the overall "planning and management" of the travel "bubble zones". Therefore, the "quality management" criteria factor provides important key decision-making for tourism stakeholders. 


\subsection{Contribution}

The present study contributes to the literature in several important aspects. First, it provided an innovative model that integrates the TRIZ and DEMATEL methods to resolve the conflicts and contradictions of the issues of stakeholders in the tourism industry, and identifies the decision-making criteria factors implemented by tourism stakeholders so that decision-makers can evaluate their industry's approach to sustainable development. Second, this study explored the practice of the identified criteria factors that provide stakeholders with insight into the existing capabilities in the implementation of decisionmaking under a crisis to bridge the research gap. Finally, in the process of constructing GMTS, the key criteria factor relationships that prioritize addressing contradictions and conflicts have practical value. The paper also provides research literature and practice implications for stakeholders in the tourism industry.

\section{Limitations and Future Research}

\subsection{Limitations}

This research reviewed the literature for a macro study of tourism stakeholders. The data came from the Asian island country of Taiwan. However, the industry model of tourism stakeholders is alike all over the world. Subsequent studies can adopt sample tourism stakeholders from different industries and countries to examine the validity of the results. This research used the TRIZ principle to formulate an expert questionnaire and then analyzed it with the DEMATEL matrix. The key criteria factors were determined by just 13 experts of tourism stakeholders. Increasing the number of tourism stakeholders involved can enable broader discussions on the implementation of GMTS. In addition, the key criteria factors in this study were concentrated during the COVID-19 period, and these key criteria factors should be further explored in the post-implementation stage.

\subsection{Future Research}

Further studies will benefit from similar research that can focus on meso and micro issues in the post-COVID-19 pandemic. For subsequent research, micro studies could be conducted in areas such as the catering industry, education departments, tourism destination management organizations, or retail stores. Data sources could be collected. Micro research could be conducted on a single industry, such as the criteria factor relationship among travel companies and related stakeholders. In the research method, the qualitative research interview method was used to deeply investigate each tourism industry and obtain key criteria factor relationships. After the DEMATEL analysis, the weights were analyzed and the problems were solved. Critical future research needs to understand these changes and make greater contributions to the tourism industry in the post-pandemic era.

Author Contributions: Conceptualization, D.-S.C.; Data curation, W.-D.W.; Formal analysis, W.-D.W.; Funding acquisition, W.-D.W.; Investigation, W.-D.W.; Methodology, D.-S.C.; Project administration, W.-D.W.; Resources, W.-D.W.; Software, W.-D.W.; Supervision, W.-D-W.; Validation, W.-D.W.; Visualization, W.-D.W.; Writing—original draft, W.-D.W.; Writing—review \& editing, W.-D.W. All authors have read and agreed to the published version of the manuscript.

Funding: This research received no external funding.

Informed Consent Statement: Not applicable.

Data Availability Statement: Not applicable.

Conflicts of Interest: The authors declare no conflict of interest. 


\section{Appendix A}

Table A1. Influence matrix.

\begin{tabular}{|c|c|c|c|c|c|c|c|c|c|c|c|c|c|c|c|c|c|c|c|c|c|c|}
\hline & 1 & 2 & 3 & & 11 & 22 & B3 & 4 & C & 2 & 3 & 4 & D1 & 2 & 3 & D4 & E1 & 22 & E3 & F1 & F2 & F3 \\
\hline A1 & & & & & & & & & & & & & & & & & & & & & & \\
\hline A2 & & & & & & & & & & & & & & & & & & & & & & \\
\hline 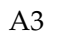 & & & & & & & & & & & & & & & & & & & & & & \\
\hline A & & & & & & & & & & & & & & & & & & & & & & \\
\hline B & & & & & & & & & & & & & & & & & & & & & & \\
\hline B2 & & & & & & & & & & & & & & & & & & & & & & \\
\hline$B$ & & & & & & & & & & & & & & & & & & & & & & \\
\hline B & & & & & & & & & & & & & & & & & & & & & 66 & \\
\hline C & & & & & & & & & & & & & & & & & & & & & & \\
\hline C & & & & & & & & & & & & & & & & & & & & & & 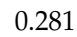 \\
\hline $\mathrm{C}^{3}$ & & & & & & & & & & & & & & & & & & & & & & \\
\hline & & & & & & & & & & & & & & & & & & & & & & \\
\hline & & & & & & & & & & & & & & & & & & & & & & \\
\hline $\mathrm{D}$ & & & & & & & & & & & & & & & & & & & & & & \\
\hline D3 & & & & & & & & & & & & & & & & & & & & & & 0.27 \\
\hline D4 & & & & & & & & & & & & & & & & & & & & & & 0.2 \\
\hline & & & & & & & & & & & & & & & & & & & & & & \\
\hline $\mathrm{F}$ & & & & & & & & & & & & & & & & & & & & & & \\
\hline E3 & & & & & & & & & & & & & & & & & & & & & & \\
\hline $\mathrm{F} 1$ & & & & & & & & & & & & & & & & & & & & & 57 & \\
\hline F2 & & & & & & & & & & & & & & & & & & & & & & \\
\hline ח & & & & & & & & & & & & & & & & & 0.267 & 0.247 & & & 0.202 & \\
\hline
\end{tabular}

\section{References}

1. World Tourism Organization (UNWTO). UNWTO International Tourism Highlights 2019 Edition; World Tourism Organization (UNWTO): Madrid, Spain, 2019; ISBN 9789284421145.

2. World Tourism Organization (UNWTO). UNWTO International Tourism Highlights 2020 Edition; World Tourism Organization (UNWTO): Madrid, Spain, 2021; ISBN 9789284422449.

3. Tourism Bureau (MOTC). Statistics of Tourism Revenue and Expenditure from 106 to 108 Years. 2020. Available online: https: / /admin.taiwan.net.tw / Handlers / FileHandler.ashx?fid=cc3a895c-9289-44b1-b43c-16e63c464283\&type=4\&no=1 (accessed on 24 February 2021).

4. Worldometer. Taiwan Population (live). Available online: https://www.worldometers.info/world-population/taiwanpopulation/ (accessed on 16 June 2021).

5. UNWTO. COVID-19 and Tourism 2020: A Year in Review. Available online: https:/ /webunwto.s3.eu-west-1.amazonaws.com/ s3fs-public/2020-12/2020_Year_in_Review_0.pdf (accessed on 1 January 2021).

6. Iaquinto, B.L. Tourist as vector: Viral mobilities of COVID-19. Dialogues Hum. Geogr. 2020, 10, 174-177. [CrossRef]

7. Novelli, M.; Burgess, L.G.; Jones, A.; Ritchie, B.W. 'No Ebola ... still doomed'-The Ebola-induced tourism crisis. Ann. Tour. Res. 2018, 70, 76-87. [CrossRef]

8. Ghaderi, Z.; Som, A.P.M.; Wang, J. Organizational Learning in Tourism Crisis Management: An Experience from Malaysia. J. Travel Tour. Mark. 2014, 31, 627-648. [CrossRef]

9. Sheller, M. Reconstructing tourism in the Caribbean: Connecting pandemic recovery, climate resilience and sustainable tourism through mobility justice. J. Sustain. Tour. 2021, 29, 1436-1449. [CrossRef]

10. Shao, Y.; Hu, Z.; Luo, M.; Huo, T.; Zhao, Q. What is the policy focus for tourism recovery after the outbreak of COVID-19? A co-word analysis. Curr. Issues Tour. 2021, 24, 899-904. [CrossRef]

11. Sigala, M. Tourism and COVID-19: Impacts and implications for advancing and resetting industry and research. J. Bus. Res. 2020, 117, 312-321. [CrossRef]

12. Yang, F.X.; Wong, I.A. The social crisis aftermath: Tourist well-being during the COVID-19 outbreak. J. Sustain. Tour. 2021, 29, 859-878. [CrossRef]

13. Hall, C.M.; Scott, D.; Gössling, S. Pandemics, transformations and tourism: Be careful what you wish for. Tour. Geogr. 2020, 22, 577-598. [CrossRef]

14. Carr, A. COVID-19, indigenous peoples and tourism: A view from New Zealand. Tour. Geogr. 2020, 22, 491-502. [CrossRef]

15. Jung, H.S.; Jung, Y.S.; Yoon, H.H. COVID-19: The effects of job insecurity on the job engagement and turnover intent of deluxe hotel employees and the moderating role of generational characteristics. Int. J. Hosp. Manag. 2021, 92, 102703. [CrossRef]

16. Richter, L.K. International Tourism and its Global Public Health Consequences. J. Travel. Res. 2003, 41, 340-347. [CrossRef]

17. Gössling, S.; Scott, D.; Hall, C.M. Pandemics, tourism and global change: A rapid assessment of COVID-19. J. Sustain. Tour. 2020, 29, 1-20. [CrossRef] 
18. Tsionas, M.G. COVID-19 and gradual adjustment in the tourism, hospitality, and related industries. Tour. Econ. 2020, 1-5. [CrossRef]

19. Önder, I.; Gunter, U. Blockchain: Is it the future for the tourism and hospitality industry? Tour. Econ. 2020, 1-9. [CrossRef]

20. Galvani, A.; Lew, A.A.; Perez, M.S. COVID-19 is expanding global consciousness and the sustainability of travel and tourism. Tour. Geogr. 2020, 22, 567-576. [CrossRef]

21. Chang, C.-L.; McAleer, M.; Ramos, V. A Charter for Sustainable Tourism after COVID-19. Sustainability 2020, 12, 3671. [CrossRef]

22. Donthu, N.; Gustafsson, A. Effects of COVID-19 on business and research. J. Bus. Res. 2020, 117, 284-289. [CrossRef] [PubMed]

23. Sikarwar, E. Time-varying foreign currency risk of world tourism industry: Effects of COVID-19. Curr. Issues Tour. 2021, 24, 1-5. [CrossRef]

24. Li, X.; Wang, C.; Ducruet, C. Globalization and Regionalization: Empirical Evidence from Itinerary Structure and Port Organization of World Cruise of Cunard. Sustainability 2020, 12, 7893. [CrossRef]

25. Radic, A.; Law, R.; Lück, M.; Kang, H.; Ariza-Montes, A.; Arjona-Fuentes, J.; Han, H. Apocalypse Now or Overreaction to Coronavirus: The Global Cruise Tourism Industry Crisis. Sustainability 2020, 12, 6968. [CrossRef]

26. Lima, S.L.; Cardoso, L.; Araújo-Vila, N.; Fraiz-Brea, J.A. Sustainability Perceptions in Tourism and Hospitality: A Mixed-Method Bibliometric Approach. Sustainability 2020, 12, 8852. [CrossRef]

27. Zhao, Z.; Cai, M.; Connor, T.; Chung, M.; Liu, J. Metacoupled Tourism and Wildlife Translocations Affect Synergies and Trade-Offs among Sustainable Development Goals across Spillover Systems. Sustainability 2020, 12, 7677. [CrossRef]

28. Alvarez-Sousa, A.; Prados, J.P. Visitor Management in World Heritage Destinations before and after Covid-19, Angkor. Sustainability 2020, 12, 9929. [CrossRef]

29. Duxbury, N.; Bakas, F.; de Castro, T.; Silva, S. Creative Tourism Development Models towards Sustainable and Regenerative Tourism. Sustainability 2020, 13, 2. [CrossRef]

30. Madeira, A.; Palrão, T.; Mendes, A. The Impact of Pandemic Crisis on the Restaurant Business. Sustainability 2020, 13, 40. [CrossRef]

31. Pan, T.; Shu, F.; Kitterlin-Lynch, M.; Beckman, E. Perceptions of cruise travel during the COVID-19 pandemic: Market recovery strategies for cruise businesses in North America. Tour. Manag. 2021, 85, 104275. [CrossRef]

32. Sánchez-Teba, E.; García-Mestanza, J.; Rodríguez-Fernández, M. The Application of the Inbound Marketing Strategy on Costa del Sol Planning \& Tourism Board. Lessons for Post-COVID-19 Revival. Sustainability 2020, 12, 9926. [CrossRef]

33. Varelas, S.; Apostolopoulos, N. The Implementation of Strategic Management in Greek Hospitality Businesses in Times of Crisis. Sustainability 2020, 12, 7211. [CrossRef]

34. Cai, G.; Hong, Y.; Xu, L.; Gao, W.; Wang, K.; Chi, X. An Evaluation of Green Ryokans through a Tourism Accommodation Survey and Customer-Satisfaction-Related CASBEE-IPA after COVID-19 Pandemic. Sustainability 2020, 13, 145. [CrossRef]

35. Kang, S.-E.; Park, C.; Lee, C.-K.; Lee, S. The Stress-Induced Impact of COVID-19 on Tourism and Hospitality Workers. Sustainability 2021, 13, 1327. [CrossRef]

36. Karagiannis, D.; Andrinos, M. The Role of Sustainable Restaurant Practices in City Branding: The Case of Athens. Sustainability 2021, 13, 2271. [CrossRef]

37. Ramkissoon, H.; Mavondo, F.; Sowamber, V. Corporate Social Responsibility at LUX* Resorts and Hotels: Satisfaction and Loyalty Implications for Employee and Customer Social Responsibility. Sustainability 2020, 12, 9745. [CrossRef]

38. Bhammar, H.; Li, W.; Molina, C.; Hickey, V.; Pendry, J.; Narain, U. Framework for Sustainable Recovery of Tourism in Protected Areas. Sustainability 2021, 13, 2798. [CrossRef]

39. Bugalski, $€$. The Undisrupted Growth of the Airbnb Phenomenon between 2014-2020. The Touristification of European Cities before the COVID-19 Outbreak. Sustainability 2020, 12, 9841. [CrossRef]

40. Fernández-Pérez, V.; Peña-García, A. The Contribution of Peripheral Large Scientific Infrastructures to Sustainable Development from a Global and Territorial Perspective: The Case of IFMIF-DONES. Sustainability 2021, 13, 454. [CrossRef]

41. García-Gallo, M.; Jiménez-Naharro, F.; Torres-García, M.; Guadix-Martín, J.; Giesecke, S. Sustainability of Spanish Tourism Start-Ups in the Face of an Economic Crisis. Sustainability 2021, 13, 2026. [CrossRef]

42. Kitamura, Y.; Karkour, S.; Ichisugi, Y.; Itsubo, N. Evaluation of the Economic, Environmental, and Social Impacts of the COVID-19 Pandemic on the Japanese Tourism Industry. Sustainability 2020, 12, 10302. [CrossRef]

43. Rubino, I.; Coscia, C.; Curto, R. Identifying Spatial Relationships between Built Heritage Resources and Short-Term Rentals before the Covid-19 Pandemic: Exploratory Perspectives on Sustainability Issues. Sustainability 2020, 12, 4533. [CrossRef]

44. Yamamura, E.; Tsutsui, Y. The Impact of Postponing 2020 Tokyo Olympics on the Happiness of O-MO-TE-NA-SHI Workers in Tourism: A Consequence of COVID-19. Sustainability 2020, 12, 8168. [CrossRef]

45. Rather, R.A. Monitoring the impacts of tourism-based social media, risk perception and fear on tourist's attitude and revisiting behaviour in the wake of COVID-19 pandemic. Curr. Issues Tour. 2021, 1-9. [CrossRef]

46. Couto, G.; Castanho, R.A.; Pimentel, P.; Carvalho, C.; Sousa, Á.; Santos, C. The Impacts of COVID-19 Crisis over the Tourism Expectations of the Azores Archipelago Residents. Sustainability 2020, 12, 7612. [CrossRef]

47. Han, H.; Lee, S.; Kim, J.; Ryu, H. Coronavirus Disease (COVID-19), Traveler Behaviors, and International Tourism Businesses: Impact of the Corporate Social Responsibility (CSR), Knowledge, Psychological Distress, Attitude, and Ascribed Responsibility. Sustainability 2020, 12, 8639. [CrossRef] 
48. Kim, E.-J.; Kim, J.; Han, S.-H. Understanding Student Acceptance of Online Learning Systems in Higher Education: Application of Social Psychology Theories with Consideration of User Innovativeness. Sustainability 2021, 13, 896. [CrossRef]

49. Liu, Y.; Chin, W.; Nechita, F.; Candrea, A. Framing Film-Induced Tourism into a Sustainable Perspective from Romania, Indonesia and Malaysia. Sustainability 2020, 12, 9910. [CrossRef]

50. Wang, F.; Xue, T.; Wang, T.; Wu, B. The Mechanism of Tourism Risk Perception in Severe Epidemic-the Antecedent Effect of Place Image Depicted in Anti-Epidemic Music Videos and the Moderating Effect of Visiting History. Sustainability 2020, $12,5454$. [CrossRef]

51. Lee, W.-J.; Kim, Y. Does VR Tourism Enhance Users' Experience? Sustainability 2021, 13, 806. [CrossRef]

52. Sun, W.; Zhang, F.; Tai, S.; Wu, J.; Mu, Y. Study on Glacial Tourism Exploitation in the Dagu Glacier Scenic Spot Based on the AHP-ASEB Method. Sustainability 2021, 13, 2614. [CrossRef]

53. Van, N.; Vrana, V.; Duy, N.; Minh, D.; Dzung, P.; Mondal, S.; Das, S. The Role of Human-Machine Interactive Devices for Post-COVID-19 Innovative Sustainable Tourism in Ho Chi Minh City, Vietnam. Sustainability 2020, 12, 9523. [CrossRef]

54. Bramwell, B.; Lane, B. Tourism Collaboration and Partnerships: Politics, Practice and Sustainability; Channel View Publications: England, UK, 2000.

55. Hall, C.M. Rethinking Collaboration and Partnership: A Public Policy Perspective. J. Sustain. Tour. 1999, 7, 274-289. [CrossRef]

56. Kock, F.; Assaf, A.G.; Tsionas, M.G. Developing Courageous Research Ideas. J. Travel Res. 2020, 59, 1140-1146. [CrossRef]

57. Lew, A.A.; Cheer, J.M.; Haywood, M.; Brouder, P.; Salazar, N.B. Visions of travel and tourism after the global COVID-19 transformation of 2020. Tour. Geogr. 2020, 22, 455-466. [CrossRef]

58. Hystad, P.W.; Keller, P.C. Towards a destination tourism disaster management framework: Long-term lessons from a forest fire disaster. Tour. Manag. 2008, 29, 151-162. [CrossRef]

59. Graci, S. Collaboration and Partnership Development for Sustainable Tourism. Tour. Geogr. 2013, 15, 25-42. [CrossRef]

60. Chang, D.-S.; Liu, S.-M.; Chen, Y.-C. Applying DEMATEL to assess TRIZ's inventive principles for resolving contradictions in the long-term care cloud system. Ind. Manag. Data Syst. 2017, 117, 1244-1262. [CrossRef]

61. Altuntas, F.; Gok, M.S. The effect of COVID-19 pandemic on domestic tourism: A DEMATEL method analysis on quarantine decisions. Int. J. Hosp. Manag. 2021, 92, 102719. [CrossRef] [PubMed]

62. Seyitoğlu, F.; Ivanov, S. Service robots as a tool for physical distancing in tourism. Curr. Issues Tour. 2021, 24, 1631-1634. [CrossRef]

63. Tappe, A.; Luhby, T. 22 Million Americans Have Filed for Unemployment Benefits in the Last Four Weeks. Available online: https:/ / edition.cnn.com/2020/04/16/economy/unemployment-benefits-coronavirus/index.html (accessed on 16 April 2020).

64. Baum, T.; Hai, N.T.T. Hospitality, tourism, human rights and the impact of COVID-19. Int. J. Contemp. Hosp. Manag. 2020, 32, 2397-2407. [CrossRef]

65. Baum, T.; Mooney, S.K.; Robinson, R.N.; Solnet, D. COVID-19's impact on the hospitality workforce-New crisis or amplification of the norm? Int. J. Contemp. Hosp. Manag. 2020, 32, 2813-2829. [CrossRef]

66. Sharma, A.; Nicolau, J.L. An open market valuation of the effects of COVID-19 on the travel and tourism industry. Ann. Tour. Res. 2020, 83, 102990. [CrossRef]

67. Filimonau, V.; Derqui, B.; Matute, J. The COVID-19 pandemic and organisational commitment of senior hotel managers. Int. J. Hosp. Manag. 2020, 91, 102659. [CrossRef] [PubMed]

68. AHLA. Report: State of Hotel Industry Six Months into COVID Pandemic. Available online: https://www.ahla.com/pressrelease/report-state-hotel-industry-six-months-covid-pandemic (accessed on 31 August 2020).

69. Wu, F.; Zhang, Q.; Law, R.; Zheng, T. Fluctuations in Hong Kong Hotel Industry Room Rates under the 2019 Novel Coronavirus (COVID-19) Outbreak: Evidence from Big Data on OTA Channels. Sustainability 2020, 12, 7709. [CrossRef]

70. Foo, L.-P.; Chin, M.-Y.; Tan, K.-L.; Phuah, K.-T. The impact of COVID-19 on tourism industry in Malaysia. Curr. Issues Tour. 2020, 1-5. [CrossRef]

71. Wen, J.; Kozak, M.; Yang, S.; Liu, F. COVID-19: Potential effects on Chinese citizens' lifestyle and travel. Tour. Rev. 2021, 76, 74-87. [CrossRef]

72. Rodríguez-Antón, J.; Alonso-Almeida, M. COVID-19 Impacts and Recovery Strategies: The Case of the Hospitality Industry in Spain. Sustainability 2020, 12, 8599. [CrossRef]

73. Aiello, F.; Bonanno, G.; Foglia, F. On the choice of accommodation type at the time of Covid-19. Some evidence from the Italian tourism sector. Curr. Issues Tour. 2020, 1-5. [CrossRef]

74. Davahli, M.R.; Karwowski, W.; Sonmez, S.; Apostolopoulos, Y. The Hospitality Industry in the Face of the COVID-19 Pandemic: Current Topics and Research Methods. Int. J. Environ. Res. Public Health 2020, 17, 7366. [CrossRef]

75. Vo-Thanh, T.; Vu, T.-V.; Nguyen, N.P.; van Nguyen, D.; Zaman, M.; Chi, H. How does hotel employees' satisfaction with the organization's COVID-19 responses affect job insecurity and job performance? J. Sustain. Tour. 2021, 29, 907-925. [CrossRef]

76. Gössling, S. Global environmental consequences of tourism. Glob. Environ. Chang. 2002, 12, 283-302. [CrossRef]

77. Hall, C.M. Biological Invasion, Biosecurity, Tourism, and Globalization of Handbook of Globalisation and Tourism; Edward Elgar: Cheltenham, UK, 2019; pp. 114-125.

78. Abu-Rayash, A.; Dincer, I. Analysis of mobility trends during the COVID-19 coronavirus pandemic: Exploring the impacts on global aviation and travel in selected cities. Energy Res. Soc. Sci. 2020, 68, 101693. [CrossRef]

79. AlJAZEERA. Coronavirus: Travel Restrictions, Border Shutdowns by Country. Available online: https://www.aljazeera.com/ news/2020/03/coronavirus-travel-restrictions-border-shutdowns-country-200318091505922.html (accessed on 3 June 2020). 
80. Freedman, D.O.; Leder, K. Influenza: Changing Approaches to Prevention and Treatment in Travelers. J. Travel Med. 2006, 12, 36-44. [CrossRef]

81. Degrowth.info. A Degrowth Perspective on the Coronavirus Crisis. Available online: https://www.degrowth.info/en/2020/03/ a-degrowth-perspective-on-the-coronavirus-crisis/\#more-473015 (accessed on 19 March 2020).

82. Luo, J.; Lam, C. Travel Anxiety, Risk Attitude and Travel Intentions towards "Travel Bubble" Destinations in Hong Kong: Effect of the Fear of COVID-19. Int. J. Environ. Res. Public Health 2020, 17, 7859. [CrossRef]

83. Allplane. Updated (31/12/20)—The 2020 Airline Bankruptcy List Now Closed. Available online: https://allplane.tv/blog/2020 /1/17/airlines-that-stopped-flying-in-2020 (accessed on 3 January 2021).

84. IATA. Slow Recovery Needs Confidence Boosting Measures. Available online: https://www.iata.org/en/pressroom/pr/2020-0 4-21-01/ (accessed on 21 April 2020).

85. Forsyth, P.; Guiomard, C.; Niemeier, H.-M. Covid-19, the collapse in passenger demand and airport charges. J. Air Transp. Manag. 2020, 89, 101932. [CrossRef]

86. ATAG. Up to Million Jobs at Risk Due to COVID-19 Aviation Downturn. Available online: https://www.atag.org/component/ news / ?view=pressrelease\&id=122 (accessed on 30 September 2020).

87. Streimikiene, D.; Svagzdiene, B.; Jasinskas, E.; Simanavicius, A. Sustainable tourism development and competitiveness: The systematic literature review. Sustain. Dev. 2021, 29, 259-271. [CrossRef]

88. Wojcieszak-Zbierska, M.; Jęczmyk, A.; Zawadka, J.; Uglis, J. Agritourism in the Era of the Coronavirus (COVID-19): A Rapid Assessment from Poland. Agriculture 2020, 10, 397. [CrossRef]

89. UNWTO. 2020: Worst Year in Tourism History with 1 Billion Fewer International Arrivals. Available online: https://www.unwto. org/news / 2020-worst-year-in-tourism-history-with-1-billion-fewer-international-arrivals (accessed on 28 January 2021).

90. Bae, S.Y.; Chang, P.-J. The effect of coronavirus disease-19 (COVID-19) risk perception on behavioural intention towards 'untact' tourism in South Korea during the first wave of the pandemic (March 2020). Curr. Issues Tour. 2021, 24, 1017-1035. [CrossRef]

91. Quang, T.D.; Tran, T.C.; Tran, V.H.; Nguyen, T.T.; Nguyen, T.T. Is Vietnam ready to welcome tourists back? Assessing COVID-19's economic impact and the Vietnamese tourism industry's response to the pandemic. Curr. Issues Tour. 2020, 1-19. [CrossRef]

92. Vaishar, A.; Št'astná, M. Impact of the COVID-19 pandemic on rural tourism in Czechia Preliminary considerations. Curr. Issues Tour. 2020, 1-5. [CrossRef]

93. Flew, T.; Kirkwood, K. The impact of COVID-19 on cultural tourism: Art, culture and communication in four regional sites of Queensland, Australia. Media Int. Aust. 2021, 178, 16-20. [CrossRef]

94. Rogerson, C.M.; Baum, T. COVID-19 and African tourism research agendas. Dev. South. Afr. 2020, 37, 1-15. [CrossRef]

95. Qiu, R.T.; Parkb, J.; Na Lic, S.; Songb, H. Social costs of tourism during the COVID-19 pandemic. Ann. Tour. Res. 2020, 84, 102994. [CrossRef] [PubMed]

96. Farzanegan, M.R.; Gholipour, H.F.; Feizi, M.; Nunkoo, R.; Andargoli, A.E. International Tourism and Outbreak of Coronavirus (COVID-19): A Cross-Country Analysis. J. Travel Res. 2021, 60, 687-692. [CrossRef]

97. Assaf, A.; Scuderi, R. COVID-19 and the recovery of the tourism industry. Tour. Econ. 2020, 26, 731-733. [CrossRef]

98. Fong, L.H.N.; Law, R.; Ye, B.H. Outlook of tourism recovery amid an epidemic: Importance of outbreak control by the government. Ann. Tour. Res. 2021, 86, 102951. [CrossRef] [PubMed]

99. McLaughlin, T. Coronavirus is Devastating Chinese Tourism. Available online: https://www.theatlantic.com/international/ archive/2020/02/economy-coronavirus-myanmar-china-tourism/606715/ (accessed on 19 February 2020).

100. Yang, Y.; Zhang, H.; Chen, X. Coronavirus pandemic and tourism: Dynamic stochastic general equilibrium modeling of infectious disease outbreak. Ann. Tour. Res. 2020, 83, 102913. [CrossRef] [PubMed]

101. Kwok, A.O.J.; Koh, S.G.M. COVID-19 and Extended Reality (XR). Curr. Issues Tour. 2021, 24, 1935-1940. [CrossRef]

102. Lee, W.C.; Ong, C.Y. Overview of rapid mitigating strategies in Singapore during the COVID-19 pandemic. Public Health 2020, 185, 15-17. [CrossRef] [PubMed]

103. Okuyama, T. Analysis of optimal timing of tourism demand recovery policies from natural disaster using the contingent behavior method. Tour. Manag. 2018, 64, 37-54. [CrossRef]

104. Djurovic, G.; Djurovic, V.; Bojaj, M.M. The macroeconomic effects of COVID-19 in Montenegro: A Bayesian VARX approach. Financial Innov. 2020, 6, 1-16. [CrossRef]

105. Baggio, R. Collaboration and cooperation in a tourism destination: A network science approach. Curr. Issues Tour. 2011, 14, 183-189. [CrossRef]

106. Denicolai, S.; Cioccarelli, G.; Zucchella, A. Resource-based local development and networked core-competencies for tourism excellence. Tour. Manag. 2010, 31, 260-266. [CrossRef]

107. Van der Zee, E.; Vanneste, D. Tourism networks unravelled; a review of the literature on networks in tourism management studies. Tour. Manag. Perspect. 2015, 15, 46-56. [CrossRef]

108. Bhati, A.S.; Agarwal, M. Vandalism control: Perception of multi-stakeholder involvement in attraction management. Curr. Issues Tour. 2020, 1-7. [CrossRef]

109. Freeman, R.E. Strategic Management: A Stakeholder Approach; Cambridge University Press: Cambridge, UK, 2010.

110. Buckley, R.; Zhong, L.; Martin, S. Mental health key to tourism infrastructure in China's new megapark. Tour. Manag. 2021, 82, 104169. [CrossRef] [PubMed] 
111. Teng, H.-Y.; Chang, S.-T. Resident perceptions and support before and after the 2018 Taichung international Flora exposition. Curr. Issues Tour. 2020, 1-20. [CrossRef]

112. Olayemi, L.O.; Boodoosingh, R.; Sam, F.A.-L. Is Samoa Prepared for an Outbreak of COVID-19? Asia Pac. J. Public Health 2020, 1-2. [CrossRef]

113. Bornhorst, T.; Ritchie, J.B.; Sheehan, L. Determinants of tourism success for DMOs \& destinations: An empirical examination of stakeholders' perspectives. Tour. Manag. 2010, 31, 572-589. [CrossRef]

114. Sharma, B.; Gursoy, D. An Examination of Changes in Residents' Perceptions of Tourism Impacts Over Time: The Impact of Residents' Socio-demographic Characteristics. Asia Pac. J. Tour. Res. 2015, 20, 1332-1352. [CrossRef]

115. Kaplan, S. An Introduction to TRIZ-the Russian Theory of Inventive Problem Solving; Ideation International Inc.: Farmington Hills, MI, USA, 1996; pp. 39-54.

116. Ilevbare, I.M.; Probert, D.; Phaal, R. A review of TRIZ, and its benefits and challenges in practice. Technovation 2013, 33, 30-37. [CrossRef]

117. Bukhman, I. TRIZ Technology for Innovation; Cubic Creativity Company: Tulsa, OK, USA, 2012.

118. Bianchi, M.; Campodall'Orto, S.; Frattini, F.; Vercesi, P. Enabling open innovation in small- and medium-sized enterprises: How to find alternative applications for your technologies. $R$ D Manag. 2010, 40, 414-431. [CrossRef]

119. Jeeradist, T.; Thawesaengskulthai, N.; Sangsuwan, T. Using TRIZ to enhance passengers' perceptions of an airline's image through service quality and safety. J. Air Transp. Manag. 2016, 53, 131-139. [CrossRef]

120. Xavier, A.F.; Naveiro, R.M.; Aoussat, A.; Reyes, T. Systematic literature review of eco-innovation models: Opportunities and recommendations for future research. J. Clean. Prod. 2017, 149, 1278-1302. [CrossRef]

121. Chechurin, L.; Borgianni, Y. Understanding TRIZ through the review of top cited publications. Comput. Ind. 2016, 82, 119-134. [CrossRef]

122. Govindan, K.; Khodaverdi, R.; Vafadarnikjoo, A. Intuitionistic fuzzy based DEMATEL method for developing green practices and performances in a green supply chain. Expert Syst. Appl. 2015, 42, 7207-7220. [CrossRef]

123. Hsu, C.-H.; Wang, F.-K.; Tzeng, G.-H. The best vendor selection for conducting the recycled material based on a hybrid MCDM model combining DANP with VIKOR. Resour. Conserv. Recycl. 2012, 66, 95-111. [CrossRef]

124. Liu, H.-C.; You, J.-X.; Lu, C.; Chen, Y.-Z. Evaluating health-care waste treatment technologies using a hybrid multi-criteria decision making model. Renew. Sustain. Energy Rev. 2015, 41, 932-942. [CrossRef]

125. Govindan, K.; Khodaverdi, R.; Vafadarnikjoo, A. A grey DEMATEL approach to develop third-party logistics provider selection criteria. Ind. Manag. Data Syst. 2016, 116, 690-722. [CrossRef]

126. Rahimdel, M.J.; Noferesti, H. Investment preferences of Iran's mineral extraction sector with a focus on the productivity of the energy consumption, water and labor force. Resour. Policy 2020, 67, 101695. [CrossRef]

127. Fang, H.; Wang, B.; Song, W. Analyzing the interrelationships among barriers to green procurement in photovoltaic industry: An integrated method. J. Clean. Prod. 2020, 249, 119408. [CrossRef]

128. Raj, A.; Kumar, J.A.; Bansal, P. A multicriteria decision making approach to study barriers to the adoption of autonomous vehicles. Transp. Res. Part A Policy Pr. 2020, 133, 122-137. [CrossRef]

129. Li, Y.-X.; Wu, Z.-X.; Dinçer, H.; Kalkavan, H.; Yüksel, S. Analyzing TRIZ-based strategic priorities of customer expectations for renewable energy investments with interval type-2 fuzzy modeling. Energy Rep. 2021, 7, 95-108. [CrossRef]

130. Zhang, X.; Su, J. A combined fuzzy DEMATEL and TOPSIS approach for estimating participants in knowledge-intensive crowdsourcing. Comput. Ind. Eng. 2019, 137, 106085. [CrossRef]

131. Nilashi, M.; Samad, S.; Manaf, A.A.; Ahmadi, H.; Rashid, T.; Munshi, A.; Almukadi, W.; Ibrahim, O.; Ahmed, O.H. Factors influencing medical tourism adoption in Malaysia: A DEMATEL-Fuzzy TOPSIS approach. Comput. Ind. Eng. 2019, 137, 1-11. [CrossRef]

132. Hsu, C.-W.; Kuo, T.-C.; Chen, S.-H.; Hu, A.H. Using DEMATEL to develop a carbon management model of supplier selection in green supply chain management. J. Clean. Prod. 2013, 56, 164-172. [CrossRef]

133. Lee, P.T.-W.; Lin, C.-W. The cognition map of financial ratios of shipping companies using DEMATEL and MMDE. Marit. Policy Manag. 2013, 40, 133-145. [CrossRef]

134. Schad, J.; Lewis, M.W.; Raisch, S.; Smith, W.K. Paradox Research in Management Science: Looking Back to Move Forward. Acad. Manag. Ann. 2016, 10, 5-64. [CrossRef]

135. Zhu, Q.; Sarkis, J.; Lai, K.-H. Supply chain-based barriers for truck-engine remanufacturing in China. Transp. Res. Part E Logist. Transp. Rev. 2014, 68, 103-117. [CrossRef]

136. Fontela, E.; Gabus, A. The DEMATEL Observer; Battelle Geneva Research Center: Geneva, Switzerland, 1976.

137. Lin, R.-J. Using fuzzy DEMATEL to evaluate the green supply chain management practices. J. Clean. Prod. 2013, 40, 32-39. [CrossRef]

138. Knight, D.W.; Xiong, L.; Lan, W.; Gong, J. Impact of COVID-19: Research note on tourism and hospitality sectors in the epicenter of Wuhan and Hubei Province, China. Int. J. Contemp. Hosp. Manag. 2020, 32, 3705-3719. [CrossRef]

139. Edwards, R.B. Bubble in, bubble out: Lessons for the COVID-19 recovery and future crises from the Pacific. World Dev. 2020, 135, 105072. [CrossRef]

140. Phillips, N. The coronavirus is here to stay-here's what that means. Nat. Cell Biol. 2021, 590, 382-384. [CrossRef] 